\title{
Progress of International Program on Hydrogen Production with the Copper-Chlorine Cycle
}

\author{
G. F. Naterer ${ }^{1 *}$, S. Suppiah ${ }^{2}$, L. Stolberg ${ }^{3}$, M. Lewis ${ }^{4}$, S. Ahmed ${ }^{5}$, Z. Wang ${ }^{6}$, M. A. Rosen ${ }^{7}$, I. Dincer ${ }^{8}$, \\ K. Gabriel ${ }^{9}$, E. Secnik ${ }^{10}$, E. B. Easton ${ }^{11}$, S. Lvov ${ }^{12}$, V. Papangelakis ${ }^{13}$, A. Odukoya ${ }^{14}$ \\ ${ }^{1,14}$ Memorial University of Newfoundland, St. John’s, Newfoundland, Canada \\ ${ }^{2,3}$ Atomic Energy of Canada Limited (AECL), Chalk River, Ontario, Canada \\ ${ }^{4,5}$ Argonne National Laboratory, Argonne, Illinois, U.S. \\ ${ }^{6-11}$ University of Ontario Institute of Technology (UOIT), Oshawa, Ontario, Canada \\ ${ }^{12}$ Pennsylvania State University, University Park, Pennsylvania, U.S. \\ ${ }^{13}$ University of Toronto, Toronto, Ontario, Canada
}

\begin{abstract}
This paper highlights the recent advances in thermochemical hydrogen production with the copper-chlorine $(\mathrm{Cu}-\mathrm{Cl})$ cycle. Extended operation and performance of $\mathrm{HCl} / \mathrm{CuCl}$ electrolysis is presented. Advances in the development of improved electrodes are presented for various electrode materials. Experimental studies for a $300 \mathrm{~cm}^{2}$ electrolytic cell show a stable current density and production at $98 \%$ of the theoretical hydrogen production rate. Long term testing of the

\footnotetext{
$1 *$ Corresponding Author: Professor and Dean, Faculty of Engineering and Applied Science, Memorial University of Newfoundland, St. John’s, NL, A1B 3X5, Email: gnaterer@mun.ca; Phone: (709) 864-8864, Fax: (709) 864-8975

${ }^{2}$ Manager, Hydrogen Isotopes Technology Branch, AECL, Chalk River, Ontario, Canada, K0J 1J0

${ }^{3}$ Scientist, Hydrogen Isotopes Technology Branch, AECL, Chalk River, Ontario, Canada, K0J 1J0

${ }^{4}$ Chemist, Chemical Engineering Division, Argonne National Laboratory, 9700 S. Cass Ave., Argonne, IL, 60439

${ }^{5}$ Chemical Engineer, Chemical Engineering Division, Argonne National Laboratory, 9700 S. Cass Avenue, Argonne, Illinois, USA, 60439

${ }^{6}$ Hydrogen Program Director, UOIT, 2000 Simcoe Street North, Oshawa, Ontario, Canada, L1H 7K4

${ }^{7}$ Professor of Mechanical Engineering, UOIT, 2000 Simcoe Street North, Oshawa, Ontario, Canada, L1H 7K4

${ }^{8}$ Professor of Mechanical Engineering, UOIT, 2000 Simcoe Street North, Oshawa, Ontario, Canada, L1H 7K4

${ }^{9}$ Professor of Mechanical Engineering, UOIT, 2000 Simcoe Street North, Oshawa, Ontario, Canada, L1H 7K4

${ }^{10}$ Research Laboratory Manager, Faculty of Engineering and Applied Science, UOIT, 2000 Simcoe Street North, Oshawa, Ontario, Canada, L1H 7K

${ }^{11}$ Associate Professor of Chemistry, UOIT, 2000 Simcoe Street North, Oshawa, Ontario, Canada, L1H 7K42

12 Professor of Energy and Mineral Engineering, Department of Materials Science and Engineering, Pennsylvania State University, 207 Hosler Building, University Park, PA 16802

${ }^{13}$ Professor of Chemical Engineering, University of Toronto, 200 College Street, Toronto, Ontario, M5S 3E5

${ }^{14}$ Research Engineer, Faculty of Engineering and Applied Science, Memorial University of Newfoundland, St. John's, Newfoundland, A1B 3X5
} 
electrolyzer for $1,000 \mathrm{~h}$ also shows a stable cell voltage. Different systems to address integration challenges are also examined for the integration of electrolysis/hydrolysis and thermolysis/electrolysis processes. New results from experiments for $\mathrm{CuCl}-\mathrm{HCl}-\mathrm{H}_{2} \mathrm{O}$ and $\mathrm{CuCl}_{2}-$ $\mathrm{HCl}-\mathrm{H}_{2} \mathrm{O}$ ternary systems are presented along with solubility data for $\mathrm{CuCl}$ in $\mathrm{HCl}-\mathrm{H}_{2} \mathrm{O}$ mixtures between 298 and $363 \mathrm{~K}$. A parametric study of multi-generation energy systems incorporating the $\mathrm{Cu}-\mathrm{Cl}$ cycle is presented with an overall energy efficiency as high as $57 \%$ and exergy efficiency of hydrogen production up to $90 \%$.

\section{Introduction}

Utilization of hydrogen as a clean energy carrier is a promising alternative to conventional fossil fuels. Sustainable, lower cost, and "green" methods of hydrogen production are needed to adopt hydrogen on a wider scale. Usage of hydrogen has the potential to significantly reduce the emissions of greenhouse gases that contribute to climate change, if produced using renewable energy sources. This is one of the reasons why hydrogen is often cited as a future energy carrier that can become a significant contributing factor to sustainable energy supply [1], as well as a prominent fuel.

Large-scale sustainable methods of hydrogen production require an energy source such as nuclear or solar energy. For large-scale capacities of hydrogen production, thermal energy can be supplied by nuclear reactors. Electrolysis is a commercially available technology that uses

electricity for water splitting and hydrogen production. Thermochemical cycles are promising water splitting alternatives that can be linked with nuclear reactors to thermally decompose water 
into oxygen and hydrogen, through a series of intermediate reactions. The $\mathrm{Cu}-\mathrm{Cl}$ cycle is a hybrid thermochemical cycle, including both electrochemical and thermal steps. This paper outlines recent advances in thermochemical hydrogen production with the $\mathrm{Cu}-\mathrm{Cl}$ cycle.

The copper-chlorine $\mathrm{Cu}-\mathrm{Cl}$ cycle is a promising cycle for hydrogen production by thermochemical water decomposition due to its lower temperature requirement and better overall efficiency than other thermochemical cycles [2-4]. The $\mathrm{Cu}-\mathrm{Cl}$ cycle consists of a closed loop of thermally driven chemical reactions, where water is decomposed into hydrogen and oxygen, and all other intermediate compounds are recycled with no emissions to the environment $[2,3,5]$. This paper focuses on the four step $\mathrm{Cu}-\mathrm{Cl}$ cycle for hydrogen production as described in Fig. 1. The four reactions of the $\mathrm{Cu}-\mathrm{Cl}$ cycle are:

$$
\begin{array}{lr}
2 \mathrm{CuCl}_{(\mathrm{aq})}+2 \mathrm{HCl}_{(\mathrm{aq})} \rightarrow 2 \mathrm{CuCl}_{2(\mathrm{aq})}+\mathrm{H}_{2(\mathrm{~g})} \text { (electrochemical) at } 25-90^{\circ} \mathrm{C} ; & \text { step (1) } \\
2 \mathrm{CuCl}_{2(\mathrm{aq})} \rightarrow 2 \mathrm{CuCl}_{2(\mathrm{~s})} \text { (physical) at } 60-200^{\circ} \mathrm{C} ; & \text { step (2) } \\
2 \mathrm{CuCl}_{2(\mathrm{~s})}+\mathrm{H}_{2} \mathrm{O}_{(\mathrm{g})} \leftrightarrow \mathrm{Cu}_{2} \mathrm{OCl}_{2(\mathrm{~s})}+2 \mathrm{HCl}_{(\mathrm{g})} \text { (hydrolysis) at } 350-450^{\circ} \mathrm{C} ; & \text { step (3) } \\
\mathrm{Cu}_{2} \mathrm{OCl}_{2(\mathrm{~s})} \rightarrow 2 \mathrm{CuCl}_{(\mathrm{l})}+\frac{1}{2} \mathrm{O}_{2(\mathrm{~g})} \text { (thermolysis) at } 520^{\circ} \mathrm{C} ; & \text { step (4) }
\end{array}
$$

In comparison to other thermochemical cycles, the $\mathrm{Cu}-\mathrm{Cl}$ cycle has the advantage of an ability to utilize low-grade waste or process heat to achieve higher thermal efficiency and lower cost of hydrogen production than other technologies [6-8]. The $\mathrm{Cu}-\mathrm{Cl}$ cycle has a reduced electrical power requirement, compared to typical water electrolysis, for its $\mathrm{CuCl} / \mathrm{HCl}$ electrolysis. The $\mathrm{CuCl}_{2}$ hydrolysis reaction and $\mathrm{Cu}_{2} \mathrm{OCl}_{2}$ thermolysis reaction form a closed loop with the $\mathrm{CuCl} / \mathrm{HCl}$ electrolyzer to produce hydrogen in the cycle. In the hydrolysis reactor, the chemical 
conversion effectiveness decreases as reactants are consumed [9]. Past studies on the conversion extent of the solid hydrolysis reactant indicated an optimal conversion of 4 mol to 15 mol of steam per mol of $\mathrm{HCl}$ produced [10]. Experimental data [11] and thermodynamic analysis [12,13] suggest an optimal temperature of the hydrolysis reactor to be approximately $375{ }^{\circ} \mathrm{C}$. Lewis et al. [14] examined the conversion extent in the $\mathrm{CuCl} / \mathrm{HCl}$ electrolyzer. In the $\mathrm{Cu}_{2} \mathrm{OCl}_{2}$ thermolysis reactor, a conversion extent of $85 \%$ was reported [14]. In this paper, the integration of the electrolyzer and hydrolysis reactor in the $\mathrm{Cu}-\mathrm{Cl}$ cycle is reported in terms of energy and mass flows. A crystallization process is also reported to reduce the quantity of $\mathrm{H}_{2} \mathrm{O}$ entering the hydrolysis reactor.

Past studies have successfully demonstrated the unit operations of each of the processes of the $\mathrm{Cu}-\mathrm{Cl}$ cycle $[15,16]$. Few studies have examined the integration of reactions and interaction between processes. The hydrolysis process and its integration with electrolysis entail significant challenges. These include the excess steam requirement of the hydrolysis reaction above the stoichiometric amount to obtain $>95 \%$ yield of $\mathrm{Cu}_{2} \mathrm{OCl}_{2}$. The concentration of the produced $\mathrm{HCl}$ in the hydrolysis reaction is not sufficient to meet the minimum requirement of the electrolysis reaction. Increasing the steam to $\mathrm{CuCl}_{2}$ ratio only further reduces the concentration of $\mathrm{HCl}$. The operating temperature of the hydrolysis and electrolysis reactions differs significantly, requiring a substantial heat exchange to condense the high temperature effluent and reheat the products for subsequent processes in the cycle $[10,15,17]$. 
Recent results of analysis of the integration of the hydrolysis and electrolysis steps were reported by Sayeed et al. [16]. Results of the kinetics in the hydrolysis reactor indicate that excess steam is required in the hydrolysis reactor, which subsequently reduces the overall efficiency of the $\mathrm{Cu}-\mathrm{Cl}$ cycle. The adverse effects of excess steam on the cycle efficiency were reduced by using a heat recovery steam generator (HRSG) to provide the excess steam required in the reaction. The results showed that steam produced in the HRSG is about 14 times higher than that observed from the stoichiometric reaction.

The paper presents recent advances toward an integrated thermochemical $\mathrm{Cu}-\mathrm{Cl}$ cycle. Individual unit operations have been developed, built and tested in combination with subsequent intermediate processes. Research and development is also reported for corrosion-resistant materials for use in the reactors, membrane development, electrode development, and crystallization studies. Results are presented and discussed for a number of case studies. The paper describes recent progress of a Canadian-led international team, including a number of institutions from Canada, U.S., Slovenia, Romania and Argentina, towards industrialization of the $\mathrm{Cu}-\mathrm{Cl}$ cycle, and extends previous reports of progress by the team $[3,16,17,21]$.

\section{Thermochemical Copper-Chlorine (Cu-Cl) Cycle}

Figure 1 depicts a schematic representation of the four step $\mathrm{Cu}-\mathrm{Cl}$ cycle for hydrogen production. There are different variations of the $\mathrm{Cu}-\mathrm{Cl}$ cycle, consisting of 3 to 5 main reactions which yield a net reaction that decomposes water into hydrogen and oxygen [14]. In this paper, the main focus is the 4-step cycle since separation of hydrolysis and drying processes provides key 
advantages of higher thermal efficiency and more viable practical adaptation [18]. The overall thermal efficiency of the $\mathrm{Cu}-\mathrm{Cl}$ cycle has been estimated to be approximately $40-43 \%[10,19]$ based on the lower heating value (LHV) of hydrogen.

In the oxygen production step of the $\mathrm{Cu}-\mathrm{Cl}$ cycle (step 4), an intermediate compound, solid copper oxychloride $\left(\mathrm{Cu}_{2} \mathrm{OCl}_{2}\right)$, is decomposed into oxygen gas and molten cuprous chloride $(\mathrm{Cu}$ $\mathrm{Cl}$ ). The solid feed of $\mathrm{Cu}_{2} \mathrm{OCl}_{2}$ is supplied to the oxygen production reactor from the $\mathrm{CuCl}_{2}$ hydrolysis reaction (step 3) that operates at a temperature of $350-450{ }^{\circ} \mathrm{C}$. Gas species leaving the oxygen reactor include oxygen gas and potentially impurities of products from side reactions, such as $\mathrm{CuCl}$ vapor, chlorine gas, $\mathrm{HCl}$ gas (trace amount) and $\mathrm{H}_{2} \mathrm{O}$ vapour (trace amount). The substances exiting the reactor are molten $\mathrm{CuCl}$, potentially solid $\mathrm{CuCl}_{2}$ from the upstream hydrolysis reaction, due to the incomplete decomposition of $\mathrm{CuCl}_{2}$ at a temperature lower than $550{ }^{\circ} \mathrm{C}[20]$, as well as reactant particles entrained by the flow of molten $\mathrm{CuCl}$.

\section{3. $\mathrm{CuCl} / \mathrm{HCl}$ Electrolysis}

Atomic Energy of Canada Limited (AECL), Gas Technology Institute (GTI) and Pennsylvania State University (PSU) are developing the $\mathrm{CuCl} / \mathrm{HCl}$ electrolyzer. Work is focused on this step because preliminary process design and economic analysis show that the major cost and energy drivers are the electrolyzer and its components [21,22]. Early experimental studies also showed that catastrophic failure of the electrolyzer could occur under some operating conditions. Research is currently focused on the determination of the optimum design and operating conditions, such as membrane type, catalyst loading, temperature and pressure, anolyte 
and catholyte compositions, and flow rate. The goal is to meet cost and energy usage targets for producing 1-10 kg of $\mathrm{H}_{2}$ /day by achieving long lifetimes and lower costs of the catalyst and membrane while maximizing current density at the desired cell potential. In the short term (2015), hydrogen produced at less the $\$ 6 / \mathrm{kg} \mathrm{H}$ by the $\mathrm{Cu}-\mathrm{Cl}$ cycle would be commercially competitive. The long term target (2025) for commercial hydrogen production is a cost of $\$ 4 / \mathrm{kg} \mathrm{H}_{2}$. Table 1 presents a summary of ongoing work at AECL, GTI and PSU and some of the conditions of their tests.

Scale-up. Testing of the one $300 \mathrm{~cm}^{2}$ cell showed a current density of $0.55 \mathrm{~A} / \mathrm{cm}^{2}$ at 0.7 V. A two $300 \mathrm{~cm}^{2}$ cell stack was then fabricated and tested to ensure that the mass flow distribution was even and that there were no shunt currents. At $0.7 \mathrm{~V}$, the current density was $0.36 \mathrm{~A} / \mathrm{cm}^{2}$ and $\mathrm{H}_{2}$ production was $98 \%$ of the theoretical value. Conversion of $\mathrm{Cu}(\mathrm{I})$ to $\mathrm{Cu}(\mathrm{II})$ was $65 \%$ when the flow rate was $210 \mathrm{~mL} / \mathrm{min}$.

Preliminary tests with the five-cell stack showed a large drop off in current within 20 minutes of the start of the test, indicating much of the $\mathrm{Cu}(\mathrm{I})$ was consumed. Two major changes in the ancillary equipment were therefore necessary - a higher capacity pump to provide greater flow rates and a redesigned recycle system with a larger capacity. An optimized flow rate will improve the reactant mass transfer uniformity to obtain maximum performance. The optimized flow rate for the single cell and five cell tests are $250 \mathrm{ml} / \mathrm{min}$ and 1 liter/min, respectively. After these changes, the polarization curves for the 5 cells overlapped each other as shown in Fig. 2 but the current density was low at $0.15 \mathrm{~A} / \mathrm{cm}^{2}$, suggesting insufficient $\mathrm{Cu}(\mathrm{I})$. Subsequent tests that 
included a longer recycle time and an increase in cathode flow rate from 600 to $800 \mathrm{~mL} / \mathrm{min}$ showed higher current densities, $0.15 \mathrm{~A} / \mathrm{cm}^{2}$ and $0.19 \mathrm{~A} / \mathrm{cm}^{2}$, respectively. Tests with various flow rates at PSU confirmed the importance of flow rate. GTI is also studying the use of the CG2 membrane in $300 \mathrm{~cm}^{2}$ cells.

Effect of increasing temperature. Details of the chemistry, the electrolyzer system and changes made to accommodate operation at $100{ }^{\circ} \mathrm{C}$ are described elsewhere [23]. The results of the tests at $40-100{ }^{\circ} \mathrm{C}$ are shown in Fig. 3 . At $0.7 \mathrm{~V}$, there was a $15 \%$ increase in current density as the temperature was increased from 80 to $100{ }^{\circ} \mathrm{C}$. Electrochemical Impedance Spectroscopy (EIS) measurements showed that the increase in current density was due to decreases in internal ohmic and charge transfer resistances [24].

Lifetime tests. The results of the 168 hour lifetime test at $80{ }^{\circ} \mathrm{C}$ are shown in Fig. 4 . The time period (168 hours) is based on limitations of the current experimental setup. The current density decreased from an initial value near $0.5 \mathrm{~A} / \mathrm{cm}^{2}$ to about $0.3 \mathrm{~A} / \mathrm{cm}^{2}$ (the milestone values) at the end of the test. The cell was operational for 168 hours while the membrane was contacted by the solution for over 400 hours. The hydrogen production rate was measured and found to be $\geq 95 \%$ of the theoretical value predicted by Faraday's Law. EIS was used to characterize the electrolyzer processes. Analysis of the EIS data is ongoing but preliminary results indicated that the internal ohmic resistance increased with time, which suggests membrane degradation.

Pt loading studies. SEM images of electrode surfaces indicated that Pt loading techniques previously used in the $\mathrm{CuCl} / \mathrm{HCl}$ electrolytic cell resulted in a dense deposit, suggesting that at 
least some of the Pt was inactive [25]. A dense deposit provides a smaller surface area for the electrochemical reaction, possibly covering Pt by carbon, which may render some Pt particles inactive. To obtain a thinner deposit, the catalyst ink was applied via an airbrush. SEM images shown in Fig. 5 show differences in the Pt surfaces with painting and airbrushing. When the airbrushed Pt loadings were reduced to 0.1 and $0.4 \mathrm{mg} / \mathrm{cm}^{2}$ on the anode and cathode, respectively, the current density was $0.55 \mathrm{~A} / \mathrm{cm}^{2}$, which was similar to that achieved when the Pt loading was $0.8 \mathrm{mg} / \mathrm{cm}^{2}$ on each electrode.

Atomic Energy of Canada Limited (AECL) has been carrying out long term performance tests to determine the long term stability of the cell voltage at a constant current density of 0.1 $\mathrm{A} / \mathrm{cm}^{2}$. For these tests the electrode area was reduced to $5 \mathrm{~cm}^{2}$. AECL's results show that the electrolyzer can operate over a long period and display stable cell voltage performance, as seen in Fig. 6 for more than 1,000 $\mathrm{h}$ of operation. The conditions used to study the long term performance of the AECL electrolyzer are summarized in Table 2. During shutdown periods, the electrolytes are still circulated through the cell. Thus, the voltage is different after each restart. During the shutdown period, all of the copper (II) in the system will have been converted back to copper (I). Also, the hydrogen present in the catholyte is purged out of the catholyte during the shutdown period. These two changes will affect the equilibrium potential of the cell. These transient periods may occur as a result of chemistry changes that occur within the system during shutdown. It is important to notice that eventually the system is able to return to a cell voltage although noisy at steady state. The noise is not always observed during experimentation, which indicates further 
investigation is required. Throughout the experiment, a drop in the catholyte $\mathrm{HCl}$ concentration is observed.

Another major objective in the development of the $\mathrm{CuCl} / \mathrm{HCl}$ electrolyzer is to suppress copper species crossover from the anolyte to the catholyte during $\mathrm{CuCl} / \mathrm{HCl}$ electrolysis. Two approaches have been adopted. The first approach is to develop membranes that can suppress copper species crossover while the second approach is more focused on the design of the electrolyzer itself. Both approaches together have allowed a significant reduction in the amount of copper species that cross over and enter the catholyte during $\mathrm{CuCl} / \mathrm{HCl}$ electrolysis. Another achievement to report has been the in-situ measurement of the various components that define the cell voltage during a long term test. The change in cell voltage with time is measured in-situ and it is periodically interrupted to measure the cell impedance. This allows the ohmic resistance of the cell to be estimated at a high frequency, where the imaginary impedance is zero. The polarization curves are also measured in-situ to determine the equilibrium potential and the activation overpotential. The ohmic resistance and the activation overpotential are used to calculate the cell voltage, which are compared to the experimentally determined data. These measurements show that the electrolyzer resistance needs to be reduced in order to improve the cell voltage performance.

Studies of copper (I) diffusion through the membrane of the electrolyzer were also investigated. Copper (I) was maintained as copper (I) by circulating the anolyte through three columns containing copper metal - the diffusing copper (I) species was $\mathrm{CuCl}_{4}{ }^{3-}$ in $11 \mathrm{M} \mathrm{HCl}$ and 
$\mathrm{CuCl}_{3}{ }^{2-}$ in $6 \mathrm{M} \mathrm{HCl}$. The catholyte copper concentrations were determined using UV-visible spectrophotometry. The results from the experiments showed a linear dependence of the catholyte copper concentration on operation time. The linear relationship was valid up to a catholyte concentration of $\sim 300 \mathrm{mg} / \mathrm{L}$. The experimental results were used to determine the diffusion coefficient, which was found to be $5 \times 10^{9} \mathrm{~cm}^{2} / \mathrm{s}$. The results showed that copper (I), an anionic copper species, can diffuse through a cation exchange membrane. Since during electrolysis an electric field is present between the electrodes, one would expect that the movement of copper (I) through the membrane would be limited as the field would oppose the negative charge on the anionic copper (I) species. However, copper (I) was still found to pass through the membrane but at a somewhat lower rate. This suggests that the driving force for diffusion is greater than the driving force for migration under the experimental conditions of electric field present during the test. In $6 \mathrm{M} \mathrm{HCl}$ the diffusion of copper (I) in the absence of an electric field was a factor of 4 higher than what was observed when $11 \mathrm{M} \mathrm{HCl}$ was studied.

A HYSYS economic model of the fully integrated $\mathrm{Cu}-\mathrm{Cl}$ cycle is being developed. The model will be optimized for economical hydrogen production by identifying the optimal cell operating conditions. A performance model of the electrolyzer will also be developed and analyzed with COMSOL.

\section{Thermolysis Process}

The oxygen decomposition reactor is the highest energy consuming device in the $\mathrm{Cu}-\mathrm{Cl}$ cycle. The thermolysis process occurs at $530{ }^{\circ} \mathrm{C}$ in the reactor and it is the highest temperature 
required in the cycle. Scaling up this process is essential in developing an integrated pilot plant of the $\mathrm{Cu}-\mathrm{Cl}$ cycle. The volume of oxygen reactor depends on the residence time, which determines the size of the reactor. The residence time of the oxygen reactor is the time required for the solid $\mathrm{Cu}_{2} \mathrm{OCl}_{2}$ particles to decompose completely into molten $\mathrm{CuCl}$ and oxygen gas. It is necessary to validate the residence time experimentally in order to calculate the volume of oxygen reactor. Residence times based on experimental studies have been reported by Rosen et al. [7]. This data is useful for scaling up the oxygen reactor.

The minimum size of the oxygen reactor is the size required by the liquid volume of molten salt without gas bubbles. The direct contact heat transfer from molten $\mathrm{CuCl}$ to solid $\mathrm{Cu}_{2} \mathrm{OCl}_{2}$ (reactant) particles reduces the heat required in the oxygen reactor. The molten bath can be sustained by the exothermic reaction occurring in the reactor. The reactor is initially filled with molten salt and solid particles are later fed continuously into the reactor.

An option for the normal configuration for the process vessel for the oxygen reactor is a vertical cylindrical section closed by dished ends [8]. Several designs are possible [26] but in order to simplify design and minimize costs, standard reactor designs are recommended. When limiting the size of oxygen reactor to a specified volume, the number of reactors can be estimated by $N=$ $V /\left(D^{2} H \pi / 4\right)$. The aspect ratio $A R$ (ratio of the reactor's height to its diameter, $H / D$ ) is selected based on the capital cost, mixing, and heat transfer characteristics of the oxygen reactor. A reasonable compromise of these competing effects is to use an aspect ratio of around 2, which is frequently used for chemical reactors [27]. 
The wall thickness of the reactor is dependent on reactor diameter, and consideration must be given to manufacturing of the reactor. Transportation of vessels over $4.6 \mathrm{~m}$ in diameter is difficult because of standard road bridge dimensions and overhead electric lines [28]. Taking these factors into consideration, the maximum reactor diameter analyzed was $4.2 \mathrm{~m}$. To avoid a very large size reactor, multiple smaller oxygen reactors can be used. Table 3 shows dimensions and numbers of oxygen reactors for different hydrogen production rates and residence times.

\section{System Integration of Unit Operations}

In this section, the experimental and numerical results of thermolysis/electrolysis integration, hydrolysis/electrolysis integration, solubility, and $\mathrm{HCl} / \mathrm{Cu}-\mathrm{Cl}_{2}$ separation processes are presented.

\subsection{Crystallization and Solubility of $\mathrm{CuCl}_{2}-\mathrm{CuCl}-\mathrm{HCl}-\mathrm{H}_{2} \mathrm{O}$ System}

The experiment on crystallization and solubility of the ternary process has been reported by Wang et al [15]. This paper reports further results from investigations carried out by researchers at UOIT. In Table 4, the crystallization properties of a $\mathrm{CuCl}_{2}-\mathrm{CuCl}-\mathrm{HCl}$ solution are presented for 1 litre of the solution between $20^{\circ} \mathrm{C}$ and $80^{\circ} \mathrm{C}$ on the basis that the crystallization process operates on the solubility curve. For each temperature, a solution is selected based on the ratio of $\mathrm{CuCl}_{2}$ $\mathrm{CuCl}-\mathrm{HCl}$ in the solution to best match the concentration of the electrolyzer effluent.

The effect of temperature of the solution on the crystallization effectiveness $(\zeta)$ is reported in Fig. 7. The amount of solids is determined by the product of crystallization effectiveness and the molar input. As presented in Fig. 7, the crystallization of $\mathrm{CuCl}$ is negligible between $80^{\circ} \mathrm{C}$ and 
$60{ }^{\circ} \mathrm{C}$, while $18 \%$ of $\mathrm{CuCl}_{2}$ is crystallized. Table 4 shows that the $\mathrm{HCl}$ concentration is increased from 6.09 to $8.55 \mathrm{M}$ from $80^{\circ} \mathrm{C}$ to $60{ }^{\circ} \mathrm{C}$, which may contribute to the relative quantities of $\mathrm{CuCl}$ and $\mathrm{CuCl}_{2}$ solids. As presented in Fig. 8, a significant portion of the energy input to the hydrolysis reactor is used to convert water to steam, particularly when the steam requirement is high. Fig. 8 also highlights the importance of maintaining a low steam requirement in the hydrolysis reactor since higher steam requirements require a significantly higher energy input than the theoretical minimum requirement for water electrolysis, $286 \mathrm{~kJ} / \mathrm{mol}$.

As illustrated in Fig. 9, the quantity of $\mathrm{H}_{2} \mathrm{O}$ in the electrolyzer effluent rises significantly with a lower conversion extent. An input electrolyte solution of $2 \mathrm{M} \mathrm{CuCl}$ and $6 \mathrm{M} \mathrm{HCl}$, and a 50 \% conversion in an electrolyzer, will produce an effluent of $1 \mathrm{M} \mathrm{CuCl}_{2}$ and $42.7 \mathrm{M}$ of $\mathrm{H}_{2} \mathrm{O}$. This increases the minimum hydrolysis input energy to $2,940 \mathrm{~kJ} / \mathrm{mol}$ of $\mathrm{CuCl}_{2}$, if the effluent stream is directly fed to the hydrolysis reactor to provide the steam and $\mathrm{CuCl}_{2}$ reactants. In contrast, utilizing a crystallizer in the temperature range of $80^{\circ} \mathrm{C}$ to $60^{\circ} \mathrm{C}$, will result is a loss of $85 \mathrm{~kJ} / \mathrm{mol}$ into the crystallizer, to produce $0.17 \mathrm{M}$ of $\mathrm{CuCl}_{2}$ solids. To produce $1 \mathrm{M}$ of $\mathrm{CuCl}_{2}$ solids will require 502 $\mathrm{kJ} / \mathrm{mol}$ of thermal energy contained in the solution. This is a comparable value in magnitude to the minimum energy requirement of the hydrolysis reactor with an excess steam requirement of 8 (507 $\mathrm{kJ} / \mathrm{mol}$ of $\mathrm{CuCl}_{2}$ ).

\subsection{Integration of Thermolysis and Electrolysis}

Experiments were performed to better understand the physics of liquid-solid systems and the dissolution rate of copper chloride $(\mathrm{CuCl})$ in hydrochloric acid $(\mathrm{HCl})$. The first experiment 
consists of dropping $\mathrm{CuCl}(\mathrm{s})$ into water to analyze the flow dynamics of the particle. The second set of experiments consisted of dropping $\mathrm{CuCl}(\mathrm{s})$ particles in $\mathrm{HCl}(\mathrm{aq})$ and recording the time required for dissolution. Initially, the particles were dropped in stagnant $\mathrm{HCl}(\mathrm{aq})$ and local saturation could be observed. To speed up the dissolution rate and avoid local saturation occurring near the particle surface, nitrogen was injected from the bottom of the container.

The results pertaining to the $\mathrm{CuCl}$ (s) particle in quiescent $12 \mathrm{M} \mathrm{HCl}(\mathrm{aq})$ are presented in Fig. 10 (a). It is observed that the particle’s area decreases linearly as follows:

$\boldsymbol{Y}=-0.0053 \boldsymbol{X}+9.4377$

where $Y$ represents the surface area, and $X$ is time. This representation returned an R-squared value of 0.98505 , which indicates a good correlation between the points. The data pertaining to the dissolution rate of $\mathrm{CuCl}(\mathrm{s})$ in $12 \mathrm{M} \mathrm{HCl}(\mathrm{aq})$ in the presence of nitrogen as the mixing agent has a similar trend as observed in Fig. 10 (b). A linear dissolution rate is observed as follows:

$\boldsymbol{Y}=-0.0125 \boldsymbol{X}+13.636$

This returned an R-squared value of 0.97971 , which indicates a good correlation between the points. The results indicate that when nitrogen bubbles are introduced as a mixing agent, the time to dissolve a particle with the same area was reduced by about half.

\subsection{Solubility Comparison of Binary and Ternary Systems}

The flow that discharges from the anode side of the copper (I) chloride electrolysis process will be a quaternary system of $\mathrm{CuCl}, \mathrm{CuCl}_{2}, \mathrm{HCl}$, and $\mathrm{H}_{2} \mathrm{O}$. After leaving the anode, this flow will 
be passed to a crystallizer to produce a concentrate of copper (II) chloride, which is recycled in the process. A quaternary solubility model is needed for the design of the cupric chloride concentration process, where it will be used to determine temperature and hydrochloric acid concentration conditions under which cupric chloride can be selectively precipitated from the solution. In the design of the electrolyzer, a quaternary solubility model is required to determine the necessary conditions for equilibrium in the electrolytic reaction.

New solubility data for the $\mathrm{CuCl}-\mathrm{HCl}-\mathrm{H}_{2} \mathrm{O}$ system was produced and covered a hydrochloric acid concentration range of 1 to $12 \mathrm{~mol} / \mathrm{kg}$ and a temperature range of $298 \mathrm{~K}$ to 363 $\mathrm{K}$ [35]. A detailed diagram of the apparatus is given in Fig. 11. The studies, which involved withdrawing and analyzing samples at regular intervals until the cuprous chloride concentration remained constant, revealed fast kinetics at room temperature, with equilibrium reached in less than five minutes for all acid concentrations. The copper concentration was determined via a complexometric titration method described by Schwarzenbach and Flaschka [29] . Hydrochloric acid concentration was determined using a TitroLine ${ }^{\circledR}$ autotitrator with 0.1000 M sodium hydroxide as titrant. Calcium 1, 2-cyclohexanediaminetetraacetic acid solution was added to the samples prior to sodium hydroxide titration to prevent interference from copper hydroxide formation. The results from the experiment are reported in Table 5. A potential source of error in this investigation is the oxidation of copper (I) to copper (II) by air. During experimentation, the reactor was monitored for any visual signs of oxidation, including colour changes in the slurry as 
well as the development of any blue hue on the cuprous chloride that had deposited on the reactor walls above the liquid level.

Thermodynamic models were produced in this investigation using OLI system software (simulation software for electrolyte chemistry) [30]. The OLI model outputs for the two ternary systems can be used to indicate the feasibility of separating cupric chloride from cuprous chloride. From the comparison in Fig. 12, the cupric chloride solubility is depressed as the hydrochloric acid concentration is increased, until it reaches a minimum, after which it increases again. At the same time, the cuprous chloride solubility continuously increases with a higher hydrochloric acid concentration. These trends yield regions of low cupric chloride solubility and high cuprous chloride solubility. This difference in solubility becomes more pronounced as the temperature decreases. The separation of cuprous from cupric chloride by selective crystallization may be feasible in these regions.

\section{Advanced Materials}

Studies were conducted to identify and test potential replacement membranes for use in the membrane electrode assembly (MEA) investigated in a previous study [22]. The primary method in this paper to prevent copper crossover is to modify the membrane through polymerization with some promising compounds such as pyrrole and/or aniline. These polymers reduce the porosity of the membrane in such a way that they allow the passage of protons but prevent or reduce other molecules, such as copper cations, to permeate to the cathode area. Such membrane materials have been shown as effective to reduce the rate of methanol crossover in direct methanol fuel cells 
(DMFC) [31-34]. The membrane materials that have been shown to have higher selectivity of protons over methanol are expected to also have higher selectivity of protons over Cu species.

\subsection{Silane Composite Electrodes}

Ceramic carbon electrodes (CCE) were produced through a sol-gel method incorporating a selection of amine containing silanes with increasing numbers of primary and secondary amines. Electrochemical analysis was performed using cell polarization, cyclic voltammetry, and electrochemical impedance spectroscopy. The materials were also characterized with thermogravametric analysis to assess bulk physical properties. Current electrode technologies rely on a Pt catalyst containing MEA designed for PEM water electrolysis [RW.ERROR - Unable to find reference:595]. Past studies have shown that a platinum catalyst is not required at the anode as the oxidation is occurring at a transition metal centre [36,37]. In aqueous media, $\mathrm{Cu}(\mathrm{I})$ will form anionic complexes such as $\mathrm{CuCl}_{2}{ }^{-}$or $\mathrm{CuCl}_{3}{ }^{2-1}$. The slow transport of these species to the anode surface severely limits the overall electrochemical reaction. By protonating existing amine groups imparted by the functionalized silanes, there should be an increase in the transport of these anionic species.

Capacitive CV's and EIS were collected in the absence of $\mathrm{CuCl}$ to analyze the surface area and ionic conductivity of the different anode materials. These measurements were made in a fullcell MEA configuration constructed from the CCE anode electrode (the test electrode), a Nafion 115 membrane, and a standard Pt-based cathode. Details of these electrochemical measurements are described in detail elsewhere [38, 39]. The CV results indicated that the capacitive surface area 
is independent of silane loading (Fig. 13). When normalized for the mass of carbon present on the CCE, the materials showed very similar capacitances. The results showed that the silane loadings between 27-53 wt\% had a negligible effect on the surface area of the carbon electrodes. This result was expected since the percentage composition by volume of silane is not significant enough to alter the surface area of the CCE.

The $\mathrm{CuCl} / \mathrm{HCl}$ electrolysis cell performance was evaluated by plotting current at cell potentials of 0.7 and $1.1 \mathrm{~V}$ as a function of anolyte flow rate (Fig. 14). Using this method, the cell response was evaluated to increase the flow at the anode surface. This can also be used to predict the cell's response to higher concentrations of anolyte materials. At $1.1 \mathrm{~V}$, all of the samples showed a linear response to increased flow rate. The $32.4 \mathrm{wt} \%$ silane showed the highest performance of all samples. The $27.2 \mathrm{wt} \%$ sample showed a steeper response to the increased flow rate meaning that at even higher flow rates, the $27.2 \mathrm{wt} \%$ sample may outperform the $32.4 \mathrm{wt} \%$ sample. Similar behavior was observed for the $0.7 \mathrm{~V}$ comparison. The $32.4 \mathrm{wt} \%$ sample also showed the highest current response at $0.7 \mathrm{~V}$. The $27.2 \mathrm{wt} \%$ sample showed very comparable currents with a steeper response to the increased flow rates (Fig. 14). While the $27.2 \mathrm{wt} \%$ sample showed a slightly lower current response, at higher flow rates or concentrations, the $27.2 \mathrm{wt} \%$ sample should perform the best of all tested CCE's.

From the produced silanes, some target composition ranges were identified (Table 6). Silane loading was found to be optimized between approximately 4.8 and $6.8 \mathrm{mmol}$ of silane per gram of carbon in the CCE material. The silane-to-carbon ration (in units of mmol gC $\mathrm{g}^{-1}$ ) value was 
found to be consistent across the three silane types tested. Comparing the three materials, it was observed that there is an increase in current response from the CCE samples from the 3aminopropyl-trimethoxysilane $(1 \mathrm{~N})$ materials to the 3-trimethoxysilyl-propyl-ethylenediamine (2N) materials, with the 3-trimethoxysilylpropyl-diethylenetriamine (3N) materials showing the best overall performance. Additionally, the $2 \mathrm{~N}$ and $3 \mathrm{~N}$ materials showed an increased stability and resistance to copper crossover. The $2 \mathrm{~N}$ and $3 \mathrm{~N}$ materials showed limiting currents comparable to or potentially better than those seen in past studies without the use of a Pt catalyst [35,40]. It is important to note that there is a discrepancy between the current responses recorded through potential stair step/LSV and those measured with potentiostatic holds. The increase in the current response from the potential stair step/LSV measurements can be attributed to a preloading of $\mathrm{CuCl}$ at the surface of the electrode.

\subsection{Nafion/polypyrrole (Ppy) Composite Membranes}

Other electrode composites have also been investigated as possible electrode membrane materials. In this section, a series of Nafion/polypyrrole (Ppy) composite membranes (Nafion NRE212, Nafion 115 (N115) (1100 EW) and Nafion 117 (N117)) were fabricated and their selectivity for protons over both $\mathrm{Cu}$ and methanol are compared. Proton conductivity was determined via electrochemical impedance spectroscopy (EIS). EIS measurements were taken by applying a $100 \mathrm{mV}$ sinusoidal voltage across the electrodes over a frequency range of $10 \mathrm{MHz}$ to $100 \mathrm{~Hz}$. All EIS data was fitted to the simple equivalent circuit, consisting of the membrane capacitance, connected in parallel to the membrane ionic resistance $\left(R_{m}\right)$ and both connected in 
series with a contact resistance. The typical EIS response is a semi-circle Nyquist plot, where the diameter of the semi-circle corresponds to $\mathrm{R}_{\mathrm{m}}$ [41-43].

Water contents obtained by Karl Fisher (KF) titration are listed in Table 7. The water content ranges from 6.1 to $16.1 \%$, for pure Nafion membranes, and from 1.7 to $6.7 \%$ for Nafion pyrrole membranes. In all cases, the presence of Ppy yielded lower water content over the unmodified membrane. This data is in agreement with the TGA data, and also prior reports that observed a decrease in water content that was ascribed to decrease porosity in the composite membranes [32].

The proton conductivities determined from these plots are listed in Table 7. All unmodified membranes displayed proton conductivity values between 0.09 and $0.10 \mathrm{~S} / \mathrm{cm}$, which is in agreement with literature values reported for Nafion [44-46]. When composites are formed, there is a significant reduction in proton conductivity in all cases. The largest reduction occurs for NRE 212, which is most likely due to the fact it is the thinnest membrane and likely contains the highest wt \% Ppy. The proton conductivities measured in this study are still in a range suitable for full cell applications and in agreement with those reported for Nafion/Ppy composites in DMFC applications [47]. The expected area specific resistances (ASR) for each membrane when assembled in an MEA configuration (i.e. through plane) are listed in Table 7.

Methanol permeability has been measured for the unmodified Nafion membranes and as well the Nafion/Ppy membranes (Table 7). The methanol permeability values measured for Nafion are comparable with those reported in the literature [48]. The values for N115 and N117 are quite 
close as expected since the samples are made by the exact same chemical process. NRE 212 has a lower permeability, which can be explained by the presence of capping groups in its structure to promote stability. Each composite shows a significant reduction in methanol permeability over its unmodified counterpart (ca. a 50 - $67 \%$ reduction).

\section{System Modeling for Cycle Enhancements}

Multi-generation systems are often attractive due to their higher energy and exergy efficiencies than individual cycles (i.e., steam or gas turbine cycles). An increase in efficiency often allows, for the same output, less resources (or exergy) consumed. This section highlights recent studies with multi-generation systems involving the $\mathrm{Cu}-\mathrm{Cl}$ cycle. Oxygen as a product of the $\mathrm{Cu}-\mathrm{Cl}$ cycle is also treated as a byproduct, which is sufficiently pure for use or sale [49] in other industrial processes. All the systems also have the capability of providing cooling, hot water and drying air.

A $\mathrm{LiBr}-\mathrm{H}_{2} \mathrm{O}$ absorption cooling system (ACS) is considered in the study for the multigeneration system, which uses excess energy of solar/nuclear heat transfer fluid to derive a cooling

effect. The absorption cooling system is used instead of a conventional cooling system in order to utilize waste heat. Hot water at $42{ }^{\circ} \mathrm{C}$ is supplied to a community by the integrated system. Also, drying air for industrial or residential applications is obtained by heating ambient air to the drying temperature $\left(50^{\circ} \mathrm{C}\right)$ using excess heat of the exhaust gases.

Solar thermal energy, concentrated by a heliostat solar tower, is the energy source of System I (Fig. 15). Molten salt (which has a composition of $60 \% \mathrm{NaNO}_{3}$ and $40 \% \mathrm{KNO}_{3}$, on a 
mass basis) is considered as the heat transfer fluid (HTF) to supply heat to the $\mathrm{Cu}-\mathrm{Cl}$ cycle. Molten salt has an advantage in that the solar heat can be stored for tens of hours for use at night, or when sunlight is not available [50]. The efficiency of the solar energy and conversion processes are not considered in the present study. Heat is supplied to the copper oxychloride decomposition step (step 4) since this step has the highest temperature heat requirement $\left(530^{\circ} \mathrm{C}\right)$ in the cycle. Heat is also transferred to the hydrolysis step (step 3) of the $\mathrm{Cu}-\mathrm{Cl}$ cycle and then hydrogen production (step 1) and drying processes (step 2). The temperature of the molten salt is increased to $650{ }^{\circ} \mathrm{C}$, so as to match the heat requirements of the $\mathrm{Cu}-\mathrm{Cl}$ cycle [50]. The temperature of the molten salt in a low temperature storage tank is higher than $250{ }^{\circ} \mathrm{C}$ which is about $30^{\circ} \mathrm{C}$ higher than the melting point of the molten salt. A hydrogen storage tank and fuel cell unit are also integrated with the $\mathrm{Cu}-\mathrm{Cl}$ cycle for energy management. Energy management with a hydrogen storage option is promising, since hydrogen can be converted to electricity efficiently in the fuel cells during peak hours.

System I also comprises a steam turbine cycle, which has a low pressure and high pressure steam turbine, and $\mathrm{LiBr}-\mathrm{H}_{2} \mathrm{O}$ ACS. The steam turbine cycle and absorption system utilize solar energy. The second $\mathrm{Cu}-\mathrm{Cl}$ based integrated system utilizes nuclear energy. A Generation IV Supercritical Water Cooled Reactor (SCWR) is a match with the $\mathrm{Cu}-\mathrm{Cl}$ cycle. The HTF can be either water or molten salt in this case. Unlike solar based systems, the nuclear plant can continuously supply heat to the $\mathrm{Cu}-\mathrm{Cl}$ cycle using water as the HTF. The coolant (water) inlet and exit temperatures are set as 350 and $625^{\circ} \mathrm{C}$, respectively. Also, the coolant pressure and mass flow 
rate are $25 \mathrm{MPa}$ and $1320 \mathrm{~kg} / \mathrm{s}$ [51]. The $\mathrm{LiBr}-\mathrm{H}_{2} \mathrm{O}$ ACS is also introduced for cooling, indicating multi-generation of hydrogen, process heat, and cooling from System II. A hydrogen storage and fuel cell unit are also used in System II (Fig. 16).

The energy efficiency of System I can be expressed as follows:

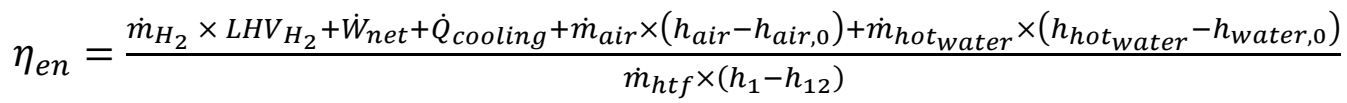

where $\dot{m}, L H V, \dot{w}_{\text {net }}, \dot{Q}_{\text {coling }}$, and $h$ are the mass flow rate, lower heating value, net work output, refrigeration capacity and specific enthalpy respectively.

The exergy efficiency of System I can be expressed as follows:

$\eta_{e x}=\frac{\dot{E x_{H_{2}}}+\dot{W}_{\text {net }}+\dot{E} x_{Q_{\text {cooling }}}+\dot{m}_{\text {air }} \times\left(e x_{\text {air }}-e x_{\text {air }, 0}\right)+\dot{m}_{\text {hot }}{ }_{\text {water }} \times\left(e x_{\text {hot }} \text { water }-e x_{\text {water }, 0}\right)}{\dot{m}_{h t f} \times\left(e x_{1}-e x_{12}\right)}$

where $\dot{E} x$ and ex are the total and specific exergy of the flow streams. The energy efficiency of System II is given as follows:

$\eta_{\text {en }}=\frac{\dot{m}_{H_{2}} \times L H V_{H_{2}}+\dot{Q}_{\text {cooling }}+\dot{m}_{\text {air }} \times\left(h_{\text {air }}-h_{\text {air }, 0}\right)+\dot{m}_{\text {hot }}{ }_{\text {water }} \times\left(h_{\text {hot }} \text { water }_{\text {water }, 0}\right)}{\dot{m}_{h t f} \times\left(h_{1}-h_{12}\right)+\dot{W}_{\text {in }, \mathrm{CuCl}}}$

where $W_{\text {in, Cucl }}$ is the work supplied to the $\mathrm{Cu}-\mathrm{Cl}$ cycle. The exergy efficiency of System II is:

$\eta_{e x}=\frac{\dot{E x_{H_{2}}}+\dot{E} x_{Q_{\text {cooling }}}+\dot{m}_{\text {air }} \times\left(e x_{\text {air }}-e x_{\text {air }, 0}\right)+\dot{m}_{\text {hot }}{ }_{\text {water }} \times\left(e x_{\text {hot }} \text { water }-e x_{\text {water }, 0}\right)}{\dot{m}_{h t f} \times\left(e x_{1}-e x_{12}\right)+\dot{W}_{\text {in, CuCl }}}$

Fig. 17(a) shows the energy and exergy efficiencies of System I and its sub-units. The overall energy efficiency of System I is about $70 \%$, whereas the exergy efficiency is $57 \%$. If the 
heat released by the condenser of the steam turbine cycle is not utilized as hot water, the energy efficiency drops to about 51\%. The exergy efficiency of the Rankine cycle (STC) is greater than its energy efficiency, since the exergy of heat input is lower than the energy of the heat input.

The energy and exergy efficiencies of System II and its sub-units are shown in Fig. 17(b). The overall energy efficiency of System II is $51 \%$ and the exergy efficiency is $41 \%$. The absorption cooling system and the $\mathrm{Cu}-\mathrm{Cl}$ cycle used in System II have similar efficiency values as System I. The energy percentages of all outputs for both systems vary by about $11 \%$ for hydrogen production. The energy percentages of hot water and drying air are $31 \%$ and $14 \%$ for System I and $19 \%$ and $20 \%$ for System II. The exergy percentages, however, are $4 \%$ in total for System I and $3 \%$ in total for System II, since drying air and hot water temperatures are close to the reference temperature, The exergies of power and hydrogen generation have the highest exergy content in System I, $27 \%$ and $64 \%$, respectively. The exergy of the hydrogen production of System II is about $94 \%$ of total exergy output of the system.

\section{Conclusions}

Recent advances in the thermochemical $\mathrm{Cu}-\mathrm{Cl}$ cycle have been presented in this paper. A long-term electrolyzer performance test of more than $1600 \mathrm{~h}$ was successfully conducted to demonstrate the promising potential of the electrolyzer for hydrogen production within the Cu-Cl cycle. Experimental and numerical results for mass transfer in multiphase systems involving gas-liquid bubble frequency and solubility of $\mathrm{CuCl}$ in $\mathrm{HCl}$ solution have been presented. The molten salt reactor design for scaling up the $\mathrm{Cu}$ - $\mathrm{Cl}$ cycle was also reported. 
Decreasing the flow rate of the anolyte in the electrolyzer caused the rate of diffusion of copper (I) through the membrane to decrease. Decreasing the $\mathrm{HCl}$ concentration from 11 to $6 \mathrm{M}$ increased the amount of copper (I) that entered the catholyte by a factor of 4. Solubility data for the $\mathrm{CuCl}-\mathrm{HCl}-\mathrm{H}_{2} \mathrm{O}$ ternary system was obtained at 298, 318, 333, 348, and $363 \mathrm{~K}$. A comparison of the $\mathrm{OLI}$ model predictions for both the $\mathrm{CuCl}-\mathrm{HCl}-\mathrm{H}_{2} \mathrm{O}$ and $\mathrm{CuCl}_{2}-\mathrm{HCl}-\mathrm{H}_{2} \mathrm{O}$ ternary systems showed regions where selective precipitation should be feasible. Thermodynamic analyses based on energy and exergy efficiencies were successfully performed to investigate the performance of the $\mathrm{Cu}$ - $\mathrm{Cl}$ cycle linked with multigeneration systems. The overall energy efficiency of System I is $70 \%$ whereas the exergy efficiency is $57 \%$. The overall energy efficiency of System II is $51 \%$ and its exergy

\section{efficiency is $41 \%$.Acknowledgements}

Support of this research from Atomic Energy of Canada Limited, Ontario Research Excellence Fund, Natural Sciences and Engineering Research Council of Canada, University Network of Excellence in Nuclear Engineering (UNENE) and the Canada Research Chairs program are gratefully acknowledged.

\section{References}

[1] Forsberg CW. Future hydrogen markets for large-scale hydrogen production systems. Int J Hydrogen Energy 2007; 32:431-9.

[2] Lewis MA, Masin JG, O'Hare PA. Evaluation of alternative thermochemical cycles, Part I: The methodology. Int J Hydrogen Energy 2009; 34: 4115-24. 
[3] Naterer GF, Suppiah S, Lewis MA, Gabriel K, Dincer I, Rosen MA, Fowler M, Rizvi G, Easton EB, Ikeda BM. Kaye MH, Lu L, Pioroi I, Spekkensk P, Tremainel P, Mostaghimim J, Avsecn J, Jiang J. Recent Canadian advances in nuclear-based hydrogen production and the thermochemical Cu-Cl cycle. Int J Hydrogen Energy 2009; 34: 2901-17.

[4] Suppiah S, Stolberg L, Boniface H, Tan G, McMahon S, York S, Zhang W. Canadian nuclear hydrogen R\&D programme: Development of the medium-temperature $\mathrm{Cu}-\mathrm{Cl}$ cycle and contributions to the high-temperature sulphur-iodine cycle. Fourth Information Exchange Meeting, Oakbrook, Illinois, USA, 14-16 April 2009.

[5] Lewis MA, Ferrandon MS, Tatterson DF, Mathias P. Evaluation of alternative thermochemical cycles-Part III further development of the Cu-Cl cycle. Int J Hydrogen Energy 2009; 34: 413645.

[6] Aghahosseini S, Dincer I, Naterer GF. Integrated gasification and $\mathrm{Cu}-\mathrm{Cl}$ cycle for trigeneration of hydrogen, steam and electricity. Int J Hydrogen Energy 2011; 36: 2845-54.

[7] Rosen MA, Naterer GF, Sadhankar R, Suppiah S. Nuclear-based hydrogen production with a thermochemical copper-chlorine cycle and supercritical water reactor: equipment scale-up and process simulation. Int J Energ Res 2012; 36: 456-45.

[8] Litwin RZ, Pinkowski SM. Solar power for thermochemical production of hydrogen. US Patent Publication US 2008/0256952; Oct 23, 2008. 
[9] Pope K, Naterer GF, Wang Z. Nitrogen carrier gas flow for reduced steam requirements of water splitting in a packed bed hydrolysis reactor. Exp Therm Fluid Sci 2012; 44: 815-24.

[10] Ferrandon MS, Lewis MA, Alvarez F, E. Shafirovich. Hydrolysis of $\mathrm{CuCl}_{2}$ in the $\mathrm{Cu}-\mathrm{Cl}$ thermochemical cycle for hydrogen production: Experimental studies using a spray reactor with an ultrasonic atomizer. Int J Hydrogen Energy 2010; 35:1895-904.

[11] Ferrandon MS, Lewis MA, Tatterson DF, Gross A, Doizi D, Croizé L, Dauvois V, Roujou J, Zanella Y, Carles P. Hydrogen production by the $\mathrm{Cu}-\mathrm{Cl}$ thermochemical cycle: Investigation of the key step of hydrolysing $\mathrm{CuCl}_{2}$ to $\mathrm{Cu}_{2} \mathrm{OCl}_{2}$ and $\mathrm{HCl}$ using a spray reactor. Int $\mathrm{J}$ Hydrogen Energy 2010; 35: 992-1000.

[12] Lewis MA, Masin JG. The evaluation of alternative thermochemical cycles-Part II: The down-selection process. Int J Hydrogen Energy 2009; 34:4125-35.

[13] Daggupati V., Naterer GF, Gabriel K, Gravelsins R, Wang Z. Equilibrium conversion in CuCl cycle multiphase processes of hydrogen production. Thermo Acta 2009; 496:117-23.

[14] Marin G, Wang Z, Naterer GF, Gabriel K. Byproducts and reaction pathways for integration of the $\mathrm{Cu}-\mathrm{Cl}$ cycle of hydrogen production. Int J Hydrogen Energy 2011; 36:13414-24.

[15] Wang Z, Daggupati V, Marin G, Pope K, Xiong Y, Secnik E, Naterer GF, Gabriel K. Towards integration of hydrolysis, decomposition and electrolysis processes of the $\mathrm{Cu}-\mathrm{Cl}$ thermochemical water splitting cycle. Int J Hydrogen Energy 2012; 37:16557-699. 
[16] Aghahosseini S, Dincer I, Naterer GF. Process integration of hydrolysis and electrolysis processes in the $\mathrm{Cu}-\mathrm{Cl}$ cycle of hydrogen production. Int J Hydrogen Energy 2013; 38:9633-43.

[17] Naterer GF, Suppiah S, Stolberg L, Lewis MA, Ferrandon M, Wang Z, Dincer I, Gabriel K, Rosen M, Secnik E. Clean hydrogen production with the $\mathrm{Cu}-\mathrm{Cl}$ cycle-progress of international consortium, I: experimental unit operations. Int J Hydrogen Energy 2011; 36:15472-85.

[18] Wang Z, Naterer GF, Gabriel K, Gravelsins R, Daggupati V. New Cu-Cl thermochemical cycle for hydrogen production with reduced excess steam requirements. Int J Green Energy 2009; 6:616-26.

[19] Chukwu C, Naterer GF, Rosen MA. Process simulation of nuclear-produced hydrogen with a Cu-Cl cycle. CNS 29th Conference, Toronto, Ontario, Canada, June 1-4, 2008.

[20] De Micco G, Bohé A, Pasquevich D. A thermogravimetric study of copper chlorination. J Alloys Compounds 2007; 437: 351-9.

[21] Lewis MA, Ahmed S, Lvov S, Fan C. II.E.2 Membrane/Electrolyzer development in the CuCl thermochemical cycle. DOE Hydrogen and Fuel Cells Program, Argonne, IL, 2012.

[22] Naterer GF, Suppiah S, Stolberg L, Lewis MA, Z. Wang Z, Dincer I, Rosen MA, Gabriel K, Secnik E, Easton EB, Pioro I, Lvov S, Jiang J, Mostaghimi J, Ikeda BM, Rizvi G, Lu L, Odukoya A, Spekkens P, Fowler M, Avsec J. Progress of international hydrogen production network for the thermochemical Cu-Cl cycle. Int J Hydrogen Energy 2013; 38: 740-59. 
[23] Schatz R, Kim S, Khurana S, Fedkin M, Lvov SN. High efficiency cucl electrolyzer for CuCl thermochemical cycle. ECS Trans 2013; 50:153-64.

[24] Khurana S, Hall DM, Schatz RS, Lvov SN. Diagnosis and modeling of the CuCl electrolyzer using electrochemical impedance spectroscopy. ECS Trans 2013; 53:41-50.

[25] Hall DM, Schatz RS, LaRow EG, Lvov SN. CuCl/HCl electrolyzer kinetics for hydrogen production via $\mathrm{Cu}-\mathrm{Cl}$ thermochemical cycle. ECS Trans 2013; 58: (in press).

[26] Oldshue JY. Fluid mixing technology. New York: McGraw-Hill; 1983.

[27] Luyben LW. Chemical reactor design and control. New Jersey: John Wiley \& sons; 2007.

[28] Himmelsbach W, Houlton D, Ortlieb D, Lovallo M. New advances in agitation technology for exothermic reactions in very large reactors. Chem eng sci 2006; 61(9):3044-52.

[29] Schwartzenbach G, Flaschka H. Complexometric titrations. London: Methuen; 1969.

[30] OLI Systems Inc., Simulation software for electrolyte chemistry, Accessed March 4, 2013 http://www.olisystems.com/.

[31] Langsdorf BL, Sultan J, Pickup PG. Partitioning and polymerization of pyrrole into perfluorosulfonate (Nafion) membranes under neutral conditions. J Phy Chem B 2003; 107: 841215. 
[32] Langsdorf BL, MacLean BJ, Halfyard JE, Hughes JA, Pickup PG. Partitioning and polymerization of pyrrole into perfluorosulfonic acid (Nafion) membranes. J Phy Chem B 2003; 107:2480-84.

[33] Xu F, Innocent C, Bonnet B, Jones D, Roziere J. Chemical modification of perfluorosulfonated membranes with pyrrole for fuel cell application: preparation, characterisation and methanol transport. Fuel Cells 2005; 5:398-405.

[34] Neburchilov V, Martin J, Wang H, Zhang J. A review of polymer electrolyte membranes for direct methanol fuel cells. J Power Sources 2007; 169:221-38.

[35] Kim S, Schatz RS, Khurana K, Fedkin MV, Wang C, Lvov SN. Advanced CuCl electrolyzer for hydrogen Ppoduction via the Cu-Cl thermochemical Cycle. ECS Trans 2011; 35: 257-65.

[36] Ranganathan S, Easton EB. Ceramic carbon electrode-based anodes for use in the Cu-Cl thermochemical cycle. Int J Hydrogen Energy 2010; 35:4871-6.

[37] Ranganathan S, Easton EB, High performance ceramic carbon electrode-based anodes for use in the $\mathrm{Cu}-\mathrm{Cl}$ thermochemical cycle for hydrogen production, Int J Hydrogen Energy 2010; 35: 1001-7.

[38] Ranganathan S, Edge PS, Easton EB. Evaluation of anode electrode materials for $\mathrm{Cu}-\mathrm{Cl} / \mathrm{HCl}$ electrolyzers for hydrogen production. ECS Trans 2012; 41:111-20. 
[39] Edge PSR, Easton EB, Comparison of novel anode materials for the production of hydrogen using $\mathrm{CuCl} / \mathrm{HCl}$ electrolyzers. ECS Trans 2013; 53:11-20.

[40] Balashov VN, Schatz RS, Chalkova E, Akinfiev NN, Fedkin MV, Lvov SN. CuCl electrolysis for hydrogen production in the $\mathrm{Cu}-\mathrm{Cl}$ thermochemical cycle. J Electrochem Soc 2011; 158:B26675.

[41] Peckham TJ, Schmeisser J, Holdcroft S. Relationships of acid and water content to proton transport in statistically sulfonated proton exchange membranes: variation of water content via control of relative humidity. J Phy Chem B 2008; 112:2848-58.

[42] De Almeida NE, Easton EB. Nafion/sulfonated silica composite membranes for PEM fuel cells. ECS Trans 2010; 28: 29-38.

[43] Nam S, Kim S, Kang Y, Lee JW, Lee K. Preparation of Nafion/sulfonated poly (phenylsilsesquioxane) nanocomposite as high temperature proton exchange membranes. J Membr Sci 2008; 322:466-74.

[44] Rodgers MP, Shi Z, Holdcroft S. Transport properties of composite membranes containing silicon dioxide and Nafion ${ }^{\circledR}$. J Membr Sci 2008; 325:346-56.

[45] Kim J, Kim S, Nam K, Kim D. Composite proton conducting membranes based on Nafion and sulfonated SiO nanoparticles. J Membr Sci 2012; 415:696-701. 
[46] Peighambardoust S, Rowshanzamir S, Amjadi M. Review of the proton exchange membranes for fuel cell applications. Int J Hydrogen Energy 2010; 35:9349-84.

[47] Easton EB, Langsdorf BL, Hughes JA, Sultan J, Qi Z, Kaufman A, Pickup PG. Characteristics of polypyrrole/nafion composite membranes in a direct methanol fuel cell. J Electrochem Soc 2003; 150: C735-39.

[48] Elabd YA, Napadensky E, Sloan JM, Crawford DM, Walker CW. Triblock copolymer ionomer membranes: part I. methanol and proton transport. J Membr Sci 2003; 217:227-42.

[49] Naterer GF, Fowler M, Cotton J, Gabriel KS. Synergistic roles of off-peak electrolysis and thermochemical production of hydrogen from nuclear energy in Canada. Int J Hydrogen Energy 2008; 33:6849-57.

[50] Wang Z, Naterer GF, Gabriel KS, Secnik E, Gravelsins R, Daggupati V. Thermal design of a solar hydrogen plant with a copper-chlorine cycle and molten salt energy storage. Int J Hydrogen Energy 2011; 36:11258-72.

[51] Pioro IL, Duffey RB. Heat transfer and hydraulic resistance at supercritical pressures in power engineering applications. New York: ASME Press; 2007, pp.99-135. 


\section{List of Figures}

Fig. 1: Schematic of the thermochemical copper-chlorine cycle

Fig. 2: Polarization curve for each cell in the 5-cell stack Conditions: Membrane Nafion ${ }^{\circledR} 112$, Catalyst loading $0.5 \mathrm{mg} / \mathrm{cm} 2$, Anolyte $1 \mathrm{M} \mathrm{CuCl}$ in $7 \mathrm{M} \mathrm{HCl}$, Catholyte $7 \mathrm{M} \mathrm{HCl}$, Flow rate 600 $\mathrm{mL} / \mathrm{min}, 60{ }^{\circ} \mathrm{C}, 1$ bar

Fig. 3: Polarization curves for 4 temperatures Conditions: Membrane Single Pressed Nafion® 117, Catalyst on each electrode: 20\% Pt on XC-72R $4 \mathrm{mg} / \mathrm{cm}^{2}$, Catalyst loading $0.8 \mathrm{mg} / \mathrm{cm}^{2}$, Pressure 1-1.3 bar, Anolyte $2 \mathrm{M} \mathrm{CuCl}$ in $7 \mathrm{M} \mathrm{HCl}$, Catholyte $7 \mathrm{M} \mathrm{HCl}$, Flow rate

Fig. 4: Current density (right) and internal ohmic resistance (left) during the 168 hour lifetime test Conditions: Membrane Single Pressed Nafion ${ }^{\circledR}$ 117, Catalyst on each electrode $20 \%$ Pt on XC72R $4 \mathrm{mg} / \mathrm{cm}^{2}$, Catalyst loading $0.8 \mathrm{mg} / \mathrm{cm}^{2} \mathrm{Pt}$, Anolyte $1-2 \mathrm{M} \mathrm{CuCl}$

Fig. 5: Two SEM images comparing catalyst application differences between painted (left) and airbrushed (right) electrodes

Fig. 6: Cell performance experiment. Anolyte: $0.5 \mathrm{M} \mathrm{CuCl}$ in $11 \mathrm{M} \mathrm{HCl}$; catholyte: $11 \mathrm{M} \mathrm{HCl}$, flow rate of $0.6 \mathrm{~L} \cdot \mathrm{min}^{-1}$, current density of $0.1 \mathrm{~A} \cdot \mathrm{cm}^{2}$

Fig. 7: Crystallization effectiveness for $1 \mathrm{~mol}$ of $\mathrm{CuCl}_{2}$ with input of $2 \mathrm{~mol} \mathrm{CuCl}$ and $6 \mathrm{~mol} \mathrm{HCl}$

Fig. 8: Minimum energy input of hydrolysis reactor

Fig. 9: Excess water with reaction extent per mol of $\mathrm{CuCl}_{2}$ 
Fig. 10: (a) Dissolution rate of solid copper (I) chloride in 12M hydrochloric acid; (b) dissolution rate of solid copper (I) chloride in 12M hydrochloric acid in the presence of nitrogen

Fig. 11: Schematic of solubility experimental apparatus for binary and ternary systems

Fig. 12: Comparison between cuprous chloride and cupric chloride solubilities in hydrochloric acid at $298 \mathrm{~K}, 323 \mathrm{~K}$ and $348 \mathrm{~K}$

Fig. 13: CVs obtained for CCE materials with varied $1 \mathrm{~N}$ silane loading. Measurements were made in the full cell configuration using $\mathrm{N}_{2}$-purged $2 \mathrm{M} \mathrm{HCl}$ as the anolyte (working electrode) and flowing hydrogen at the cathode (reference and counter electrode) at a sweep rate of $10 \mathrm{mV} / \mathrm{s}$. Data is shown with current normalized for (a) geometric surface area and for (b) mass of carbon.

Fig. 14: Variation in current densities obtained with anolyte flow rates during $\mathrm{CuCl} / \mathrm{HCl}$ electrolysis using for CCE anodes containing different amounts of $1 \mathrm{~N}$ silane at cell potentials of (a) $1.1 \mathrm{~V}$ and (b) $0.7 \mathrm{~V}$. Measurements were made at $25^{\circ} \mathrm{C}$ with $0.2 \mathrm{M} \mathrm{CuCl}$ in $2 \mathrm{M} \mathrm{HCl}$ flowing at the anode, and pure water flowing at the cathode

Fig. 15: Schematic diagram of System I

Fig. 16: Schematic diagram of System II

Fig. 17: Energy and exergy efficiency of (a) System I and (b) System II 


\begin{tabular}{|ccccc|}
\hline Institution & Study Objectives & $\begin{array}{c}\text { Active } \\
\text { Area } \\
\left(\mathrm{cm}^{2}\right)\end{array}$ & $\begin{array}{c}\text { Temperature, } \\
{ }^{\circ} \mathrm{C}\end{array}$ & $\begin{array}{c}\mathrm{HCl} \\
\text { concentration, M }\end{array}$ \\
\hline AECL & Long term CuCl/HCl cell & 5 & 45 & $11 \mathrm{M}$ \\
& performance studies & & & $11 \mathrm{M}$ \\
\hline AECL & Copper (I) diffusion studies & 25 & 45 & $6-7$ \\
\hline GTI & Scale-up & 300 & 60 & $6-7$ \\
& Increase to 5-cell stack & & & $6-7$ \\
\hline GTI & Membrane & 6.45 & 60 & $40-100$ \\
\hline PSU & Effect of temperature & 5 & & \\
\hline
\end{tabular}




\begin{tabular}{|lllll|}
\hline PSU & Lifetime & 5 & 80 & $6-7$ \\
\hline PSU & Pt loading & 5 & 80 & $6-7$ \\
\hline
\end{tabular}

Table 1: Summary of ongoing work at AECL, GTI and PSU and conditions of the tests

\begin{tabular}{|ll|}
\hline Anolyte & $0.5 \mathrm{M} \mathrm{CuCl}$ in $11 \mathrm{M} \mathrm{HCl}$ \\
\hline Anode & Catalyst free Graphite \\
\hline
\end{tabular}




\begin{tabular}{|ll|}
\hline Cathode & Pt Electrocatalyst \\
\hline Membrane & Nafion ${ }^{\circledR} \mathrm{N} 1110$ \\
\hline Current Density & $0.1 \mathrm{~A} / \mathrm{cm}^{2}$ \\
\hline Temperature & $45^{\circ} \mathrm{C}$ \\
\hline Catholyte & $11 \mathrm{M} \mathrm{HCl}$ \\
\hline Catholyte Flow Rate & $0.6 \mathrm{~L} / \mathrm{min}$ \\
\hline Anolyte Flow Rate & $0.6 \mathrm{~L} / \mathrm{min}$ \\
\hline Electrode Area & $5 \mathrm{~cm}^{2}$ \\
\hline
\end{tabular}

Table 2: Experimental conditions during long term $\mathrm{CuCl} / \mathrm{HCl}$ electrolysis experiments 


\begin{tabular}{|clcc|}
\hline $\begin{array}{c}\text { Residence Time } \\
\text { (h) }\end{array}$ & $\begin{array}{c}\mathbf{H}_{2} \\
\text { (ton/day) }\end{array}$ & $\begin{array}{c}\mathbf{O}_{2} \\
\text { (ton/day) }\end{array}$ & $\mathbf{D}(\mathbf{m}) \times \mathbf{H}(\mathbf{m}) \times \mathbf{N}$ \\
\hline & 100,000 & 800,000 & $4.14 \times 8.29 \times 2$ \\
2 & 50,000 & 400,000 & $4.14 \times 8.29 \times 1$ \\
& 25,000 & 200,000 & $3.29 \times 6.58 \times 1$ \\
\hline \multirow{3}{*}{1} & 100,000 & 800,000 & $4.14 \times 8.29 \times 1$ \\
& 50,000 & 400,000 & $3.29 \times 6.58 \times 1$ \\
& 25,000 & 200,000 & $2.61 \times 5.22 \times 1$ \\
\hline & 100,000 & 800,000 & $3.29 \times 6.58 \times 1$ \\
0.5 & 50,000 & 400,000 & $2.61 \times 5.22 \times 1$ \\
& 25,000 & 200,000 & $2.07 \times 4.14 \times 1$ \\
\hline
\end{tabular}

Table 3: Dimensions and numbers of oxygen reactors (neglecting bubble volume) for different hydrogen production rates and different residence times 


\begin{tabular}{|ccccccc|}
\hline & \multicolumn{2}{c}{$\begin{array}{c}\text { Saturated solution for } \mathbf{1} \text { litre of } \\
\text { solution [mol] }\end{array}$} & \multicolumn{3}{c|}{$\begin{array}{c}\text { Saturated solution for } 1 \text { litre of solution } \\
\text { normalized to a constant quantity of HCl [mol] }\end{array}$} \\
\hline $\mathrm{T}\left[{ }^{\circ} \mathrm{C}\right]$ & $\mathrm{CuCl}$ & $\mathrm{CuCl}_{2}$ & $\mathrm{HCl}$ & $\mathrm{CuCl}$ & $\mathrm{CuCl}_{2}$ & $\mathrm{HCl}$ \\
\hline 20 & 1.46 & 2.31 & 8.66 & 1.03 & 1.63 & 6.09 \\
\hline 40 & 1.68 & 3.06 & 9.73 & 1.05 & 1.92 & 6.09 \\
\hline 60 & 2.08 & 3.26 & 8.55 & 1.48 & 2.32 & 6.09 \\
\hline 80 & 1.48 & 2.82 & 6.09 & 1.48 & 2.82 & 6.09 \\
\hline
\end{tabular}

Table 4: Crystallization properties 


\begin{tabular}{|llllllllll|}
\hline \multicolumn{2}{|c}{$298 \mathrm{~K}$} & \multicolumn{2}{c}{$318 \mathrm{~K}$} & \multicolumn{2}{c}{$333 \mathrm{~K}$} & \multicolumn{2}{c|}{$348 \mathrm{~K}$} & \multicolumn{2}{c|}{$363 \mathrm{~K}$} \\
\hline $\begin{array}{l}\mathrm{HCl} \\
(\mathrm{mol} / \mathrm{kg})\end{array}$ & $\begin{array}{l}\mathrm{CuCl} \\
(\mathrm{mol} / \mathrm{kg})\end{array}$ & $\begin{array}{l}\mathrm{HCl} \\
(\mathrm{mol} / \mathrm{kg})\end{array}$ & $\begin{array}{l}\mathrm{CuCl} \\
(\mathrm{mol} / \mathrm{kg})\end{array}$ & $\begin{array}{l}\mathrm{HCl} \\
(\mathrm{mol} / \mathrm{kg})\end{array}$ & $\begin{array}{l}\mathrm{CuCl} \\
(\mathrm{mol} / \mathrm{kg})\end{array}$ & $\begin{array}{l}\mathrm{HCl} \\
(\mathrm{mol} / \mathrm{kg})\end{array}$ & $\begin{array}{l}\mathrm{CuCl} \\
(\mathrm{mol} / \mathrm{kg})\end{array}$ & $\begin{array}{l}\mathrm{HCl} \\
(\mathrm{mol} / \mathrm{kg})\end{array}$ & $\begin{array}{l}\mathrm{CuCl} \\
(\mathrm{mol} / \mathrm{kg})\end{array}$ \\
\hline 1.2820 & 0.1175 & 1.0811 & 0.1379 & 1.0867 & 0.2043 & 1.3302 & 0.3350 & 1.3622 & 0.4463 \\
\hline 3.7856 & 0.6702 & 3.8032 & 0.9109 & 3.8076 & 1.0734 & 3.8083 & 1.3181 & 3.9267 & 1.6366 \\
\hline 6.1608 & 1.5819 & 6.2678 & 1.9905 & 6.3385 & 2.2578 & 6.4787 & 2.6679 & 7.2798 & 3.5526 \\
\hline 7.1370 & 1.9815 & 7.1568 & 2.4272 & 7.0652 & 2.6135 & 7.1835 & 3.1121 & 9.5042 & 4.5744 \\
\hline 10.0924 & 3.0516 & 10.3550 & 3.7892 & 10.2655 & 4.0062 & 10.1334 & 4.4491 & 11.3487 & 5.4435 \\
\hline 11.7939 & 3.7330 & 10.9241 & 4.0662 & 11.8436 & 4.7969 & 11.9511 & 5.2175 & & \\
\hline
\end{tabular}

Table 5: Cuprous chloride solubility in hydrochloric acid at temperatures from $298 \mathrm{~K}$ to $363 \mathrm{~K}$ 


\begin{tabular}{|ccccc|}
\hline $\begin{array}{c}\text { Sample } \\
\text { Code }\end{array}$ & $\begin{array}{c}\mathbf{w t} \% \\
\text { Silane }\end{array}$ & $\begin{array}{c}\text { Mass Loading } \\
\left(\mathbf{m g} / \mathbf{c m}^{2}\right)\end{array}$ & $\begin{array}{c}\text { Carbon Loading } \\
\left(\mathbf{m g} / \mathbf{c m}^{\mathbf{2}}\right)\end{array}$ & $\begin{array}{c}\mathbf{m M o l} \\
\mathbf{S i} / \mathbf{g c}\end{array}$ \\
\hline B1P73S2 & 27.1790 & 1.78 & 1.2962 & 3.3930 \\
\hline B1P69S1 & 32.4223 & 2.66 & 1.7976 & 4.3616 \\
\hline B1P69S2 & 50.7222 & 2.79 & 1.3749 & 9.3574 \\
\hline B1P69S3 & 53.4536 & 3.65 & 1.6989 & 10.4399 \\
\hline B1P60S2 & 62.4869 & 4.24 & 1.5906 & 15.1431 \\
\hline
\end{tabular}

Table 6: 3-Aminopropyl-trimethoxysilane (1N) full cell CCE sample information 


\begin{tabular}{|c|c|c|c|c|c|c|c|}
\hline Membrane & $\begin{array}{c}\text { loss \% at } \\
200{ }^{\circ} \mathrm{C} \\
\text { (TGA) }\end{array}$ & $\begin{array}{l}\text { wt } \% \text { at } \\
900{ }^{\circ} \mathrm{C} \\
\text { (TGA) }\end{array}$ & $\begin{array}{c}\% \\
\mathrm{H}_{2} \mathrm{O} \\
\mathrm{KF}\end{array}$ & $\begin{array}{c}\sigma_{H^{+}} \\
S / \mathbf{c m}\end{array}$ & $\begin{array}{c}\text { ASR } \\
\Omega \mathrm{cm}^{2}\end{array}$ & $\begin{array}{c}P_{\mathrm{MeOH}} \\
\times 10^{6} \mathrm{~cm}^{2} / \mathrm{s}\end{array}$ & $\begin{array}{c}P_{\mathrm{Cu}} \\
\times 10^{6} \mathrm{~cm}^{2} / \mathrm{s}\end{array}$ \\
\hline NRE212 & 14.02 & 0.02 & 6.44 & 0.1026 & 0.0495 & 0.953 & 0.637 \\
\hline NRE212/Ppy & 5.75 & 6.124 & 4.17 & 0.0133 & 0.382 & 0.361 & $\mathrm{n} / \mathrm{a}$ \\
\hline N115 & 8.67 & 0.03 & 6.12 & 0.0905 & 0.140 & 1.520 & 0.686 \\
\hline N115/Ppy & 6.53 & 7.22 & 1.70 & 0.0149 & 0.852 & 0.557 & $\mathrm{n} / \mathrm{a}$ \\
\hline N117 & 14.63 & 0.00 & 16.05 & 0.0973 & 0.188 & 1.693 & 1.05 \\
\hline N117/Ppy & 8.58 & 5.74 & 6.68 & 0.0330 & 0.555 & 0.847 & $\mathrm{n} / \mathrm{a}$ \\
\hline
\end{tabular}

Table 7: Summary of membrane physical properties $(A S R=$ area specific resistance 


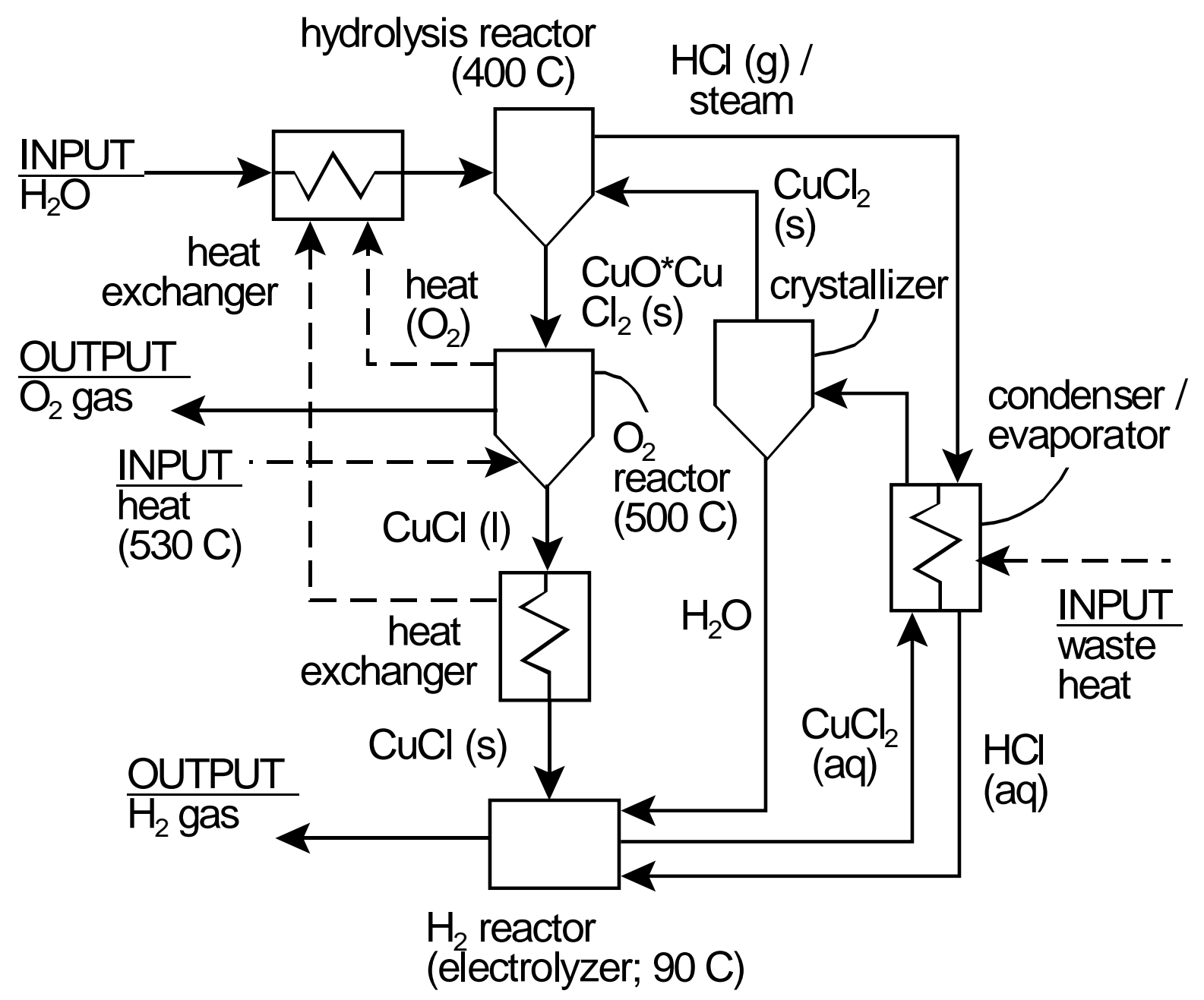

Fig. 1 


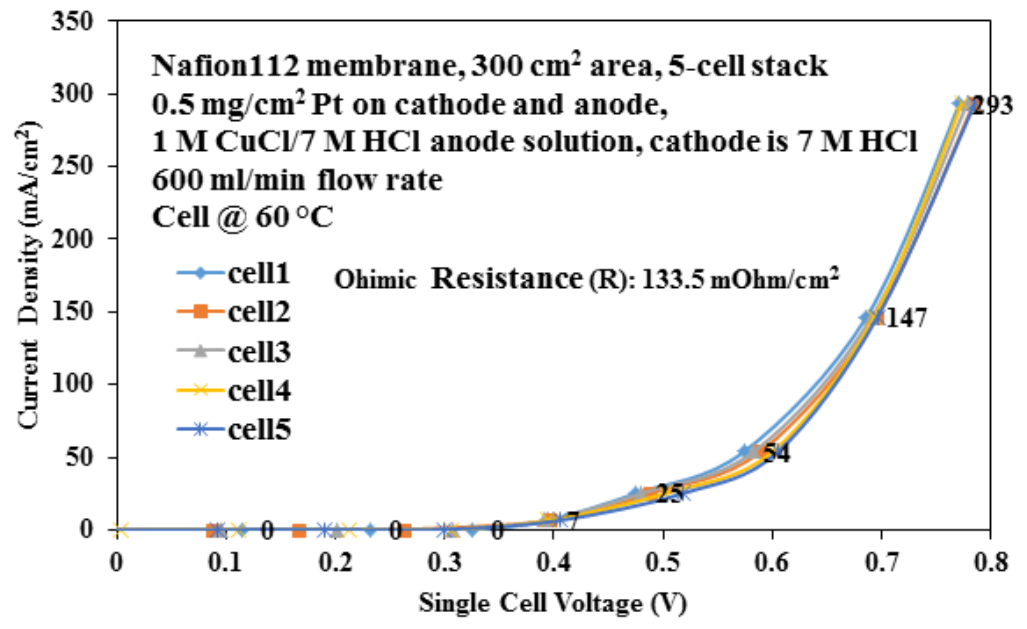

Fig. 2 


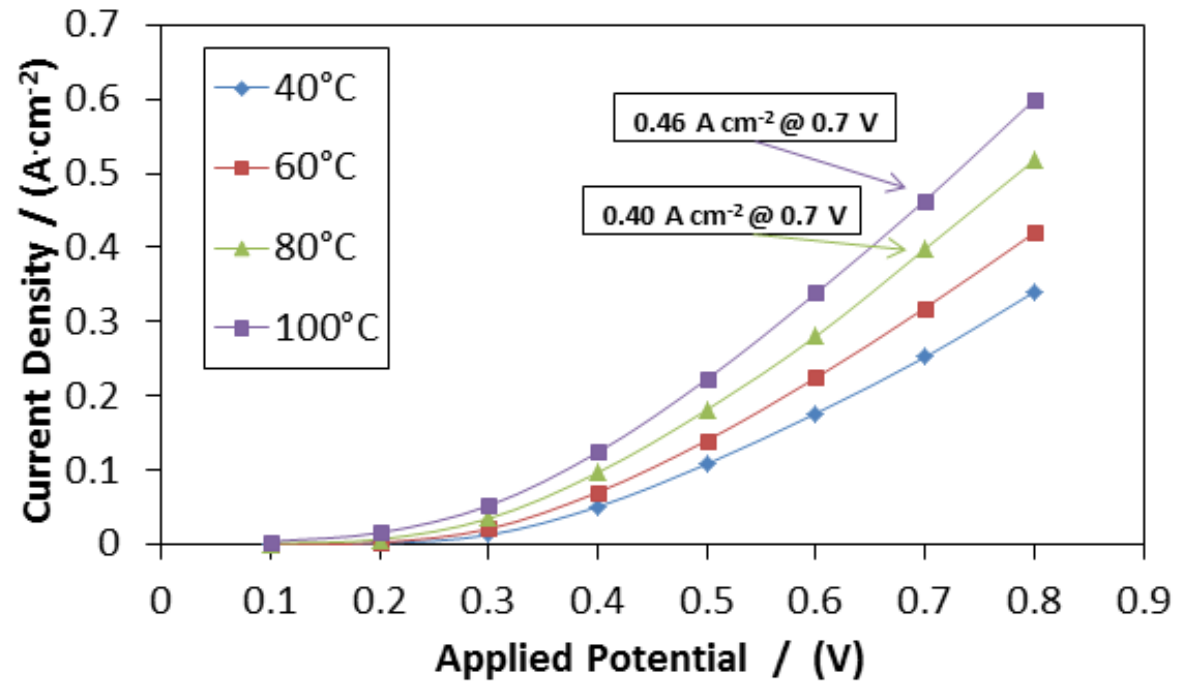

Fig. 3 


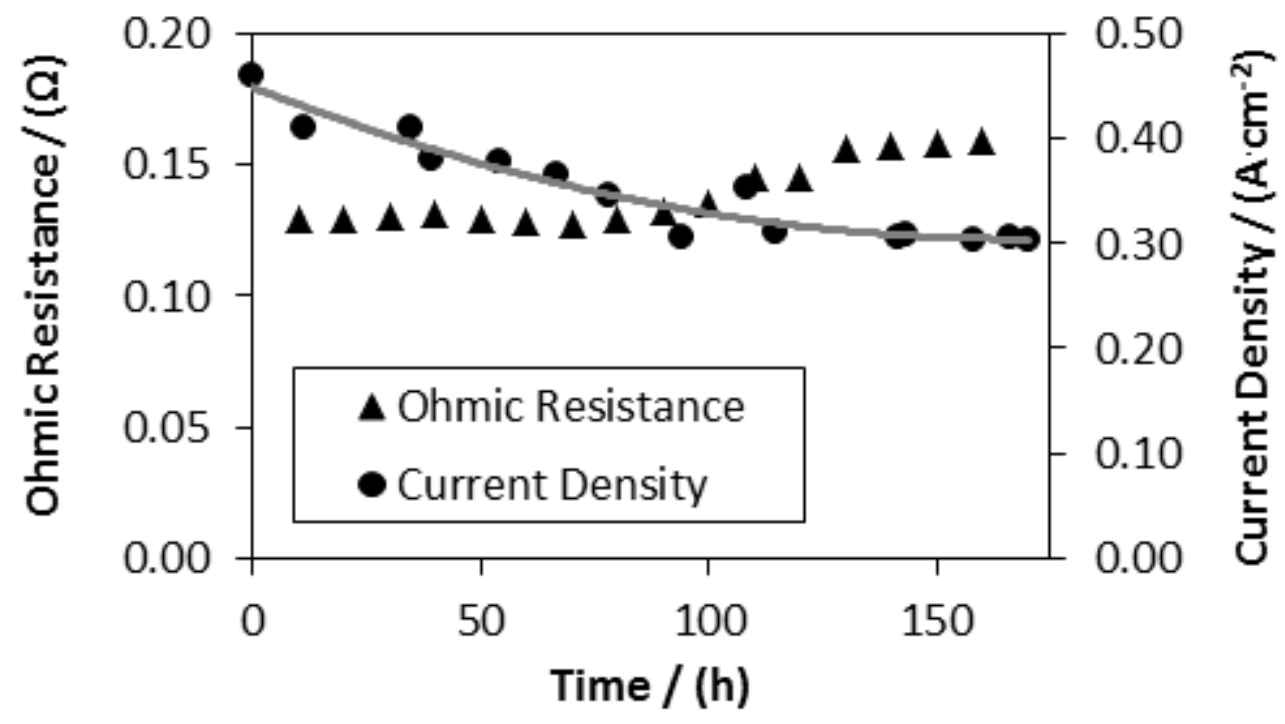


Fig. 4 


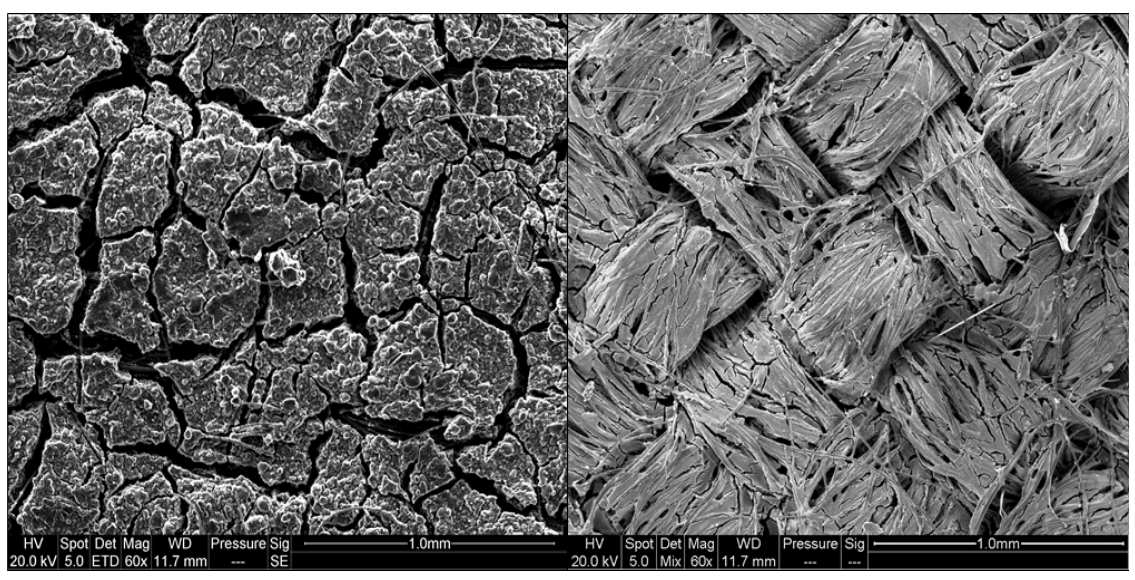

Fig. 5 


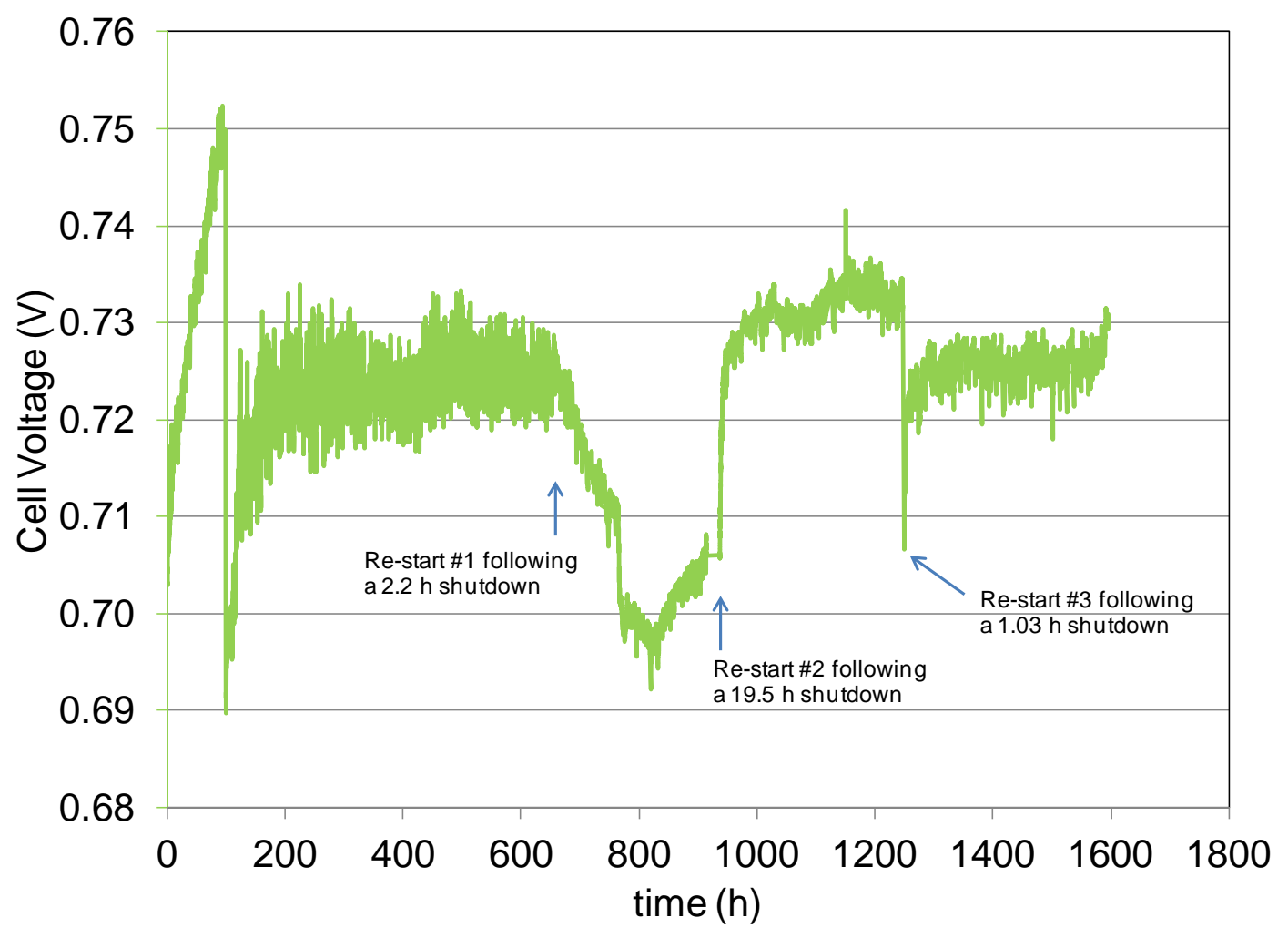

51 
Fig. 6 


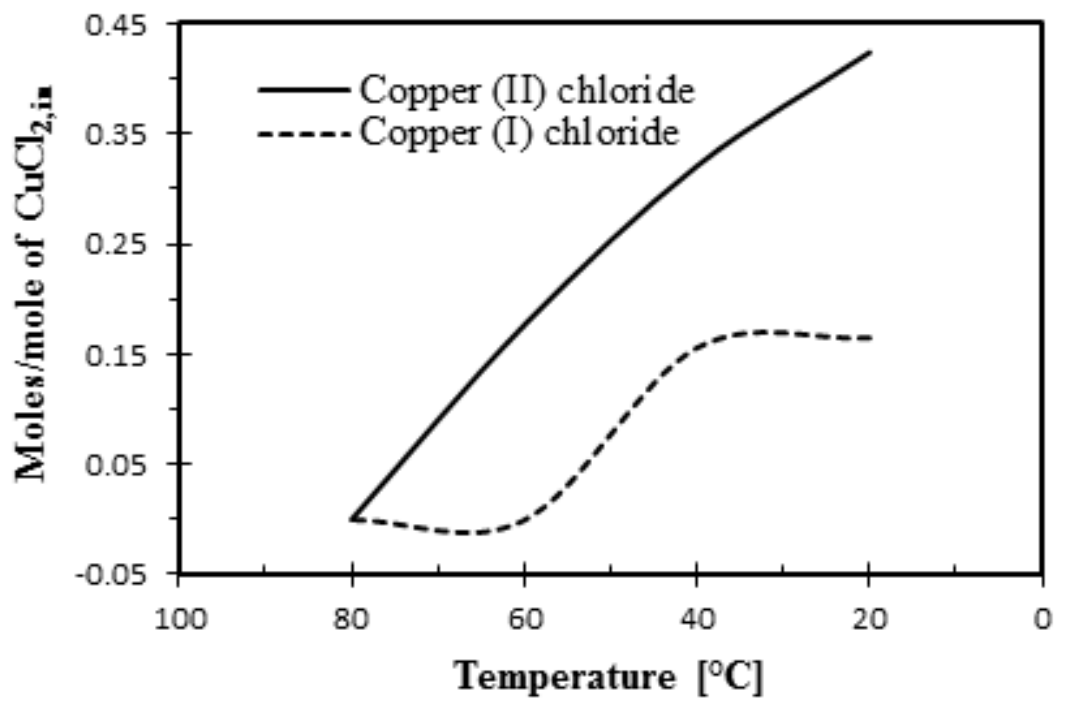

Fig. 7 


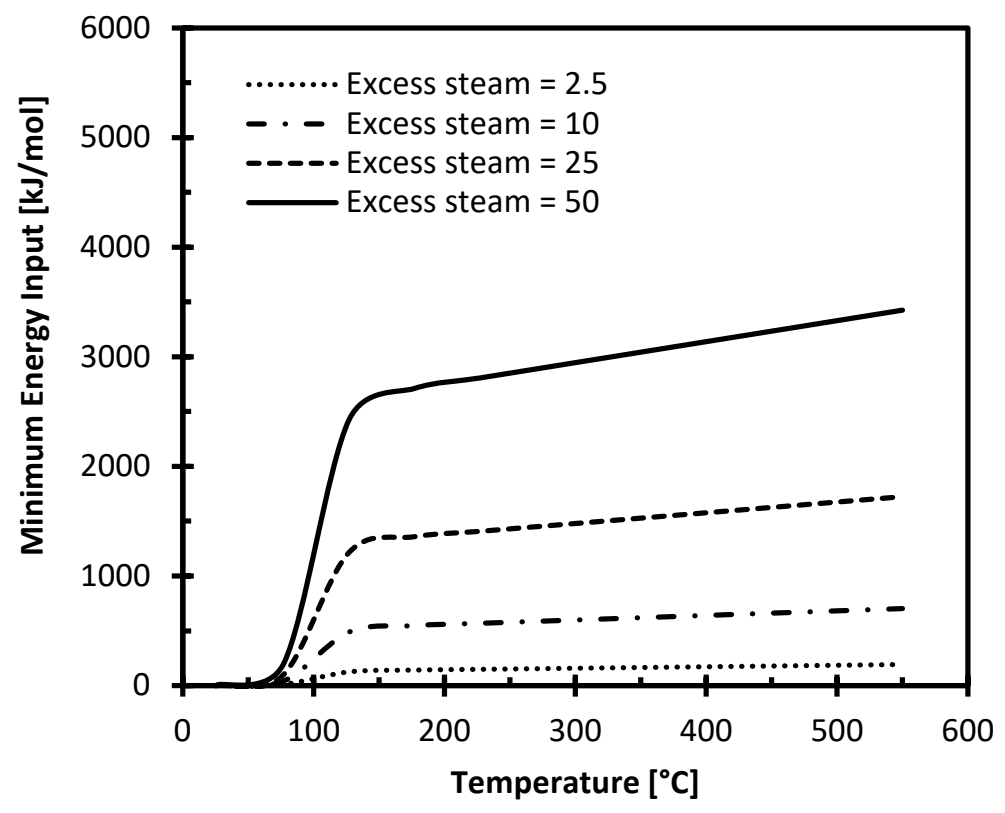

Fig. 8 


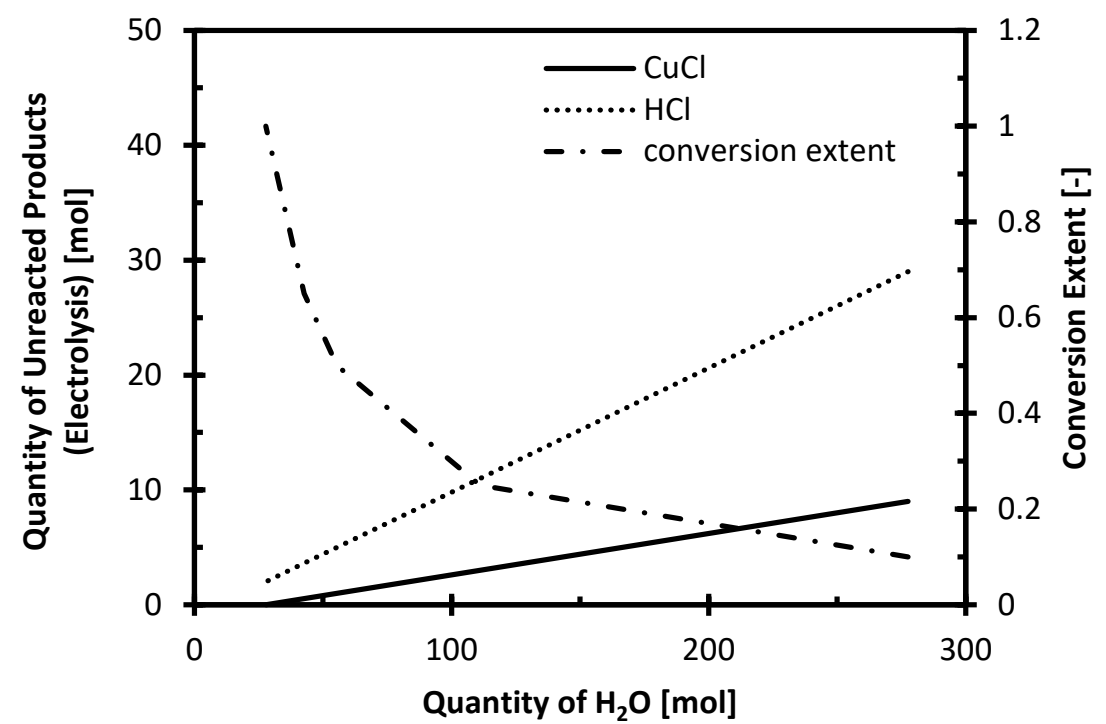

Fig. 9 


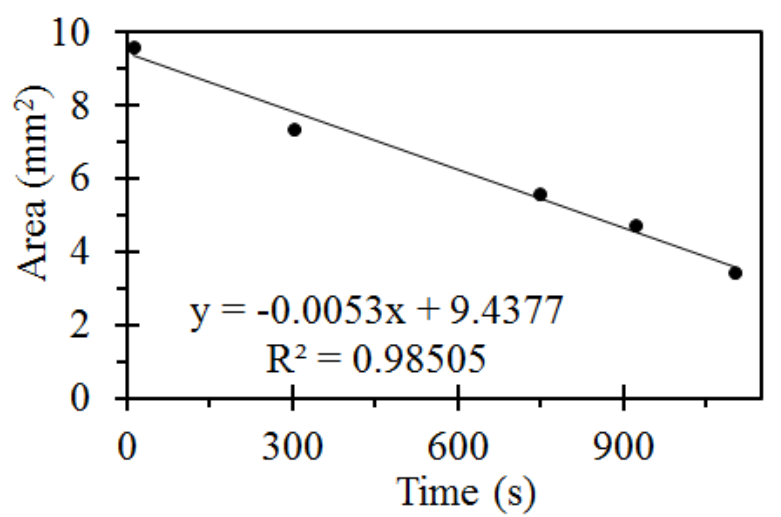

(a)

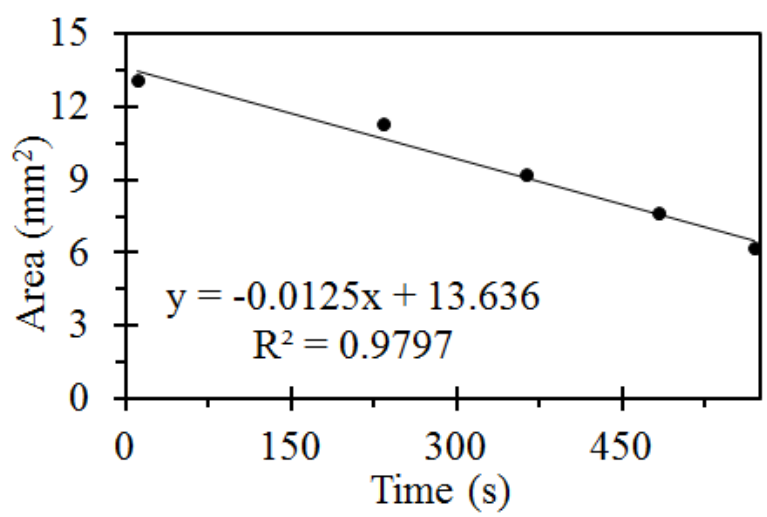

(b)

Fig. 10 


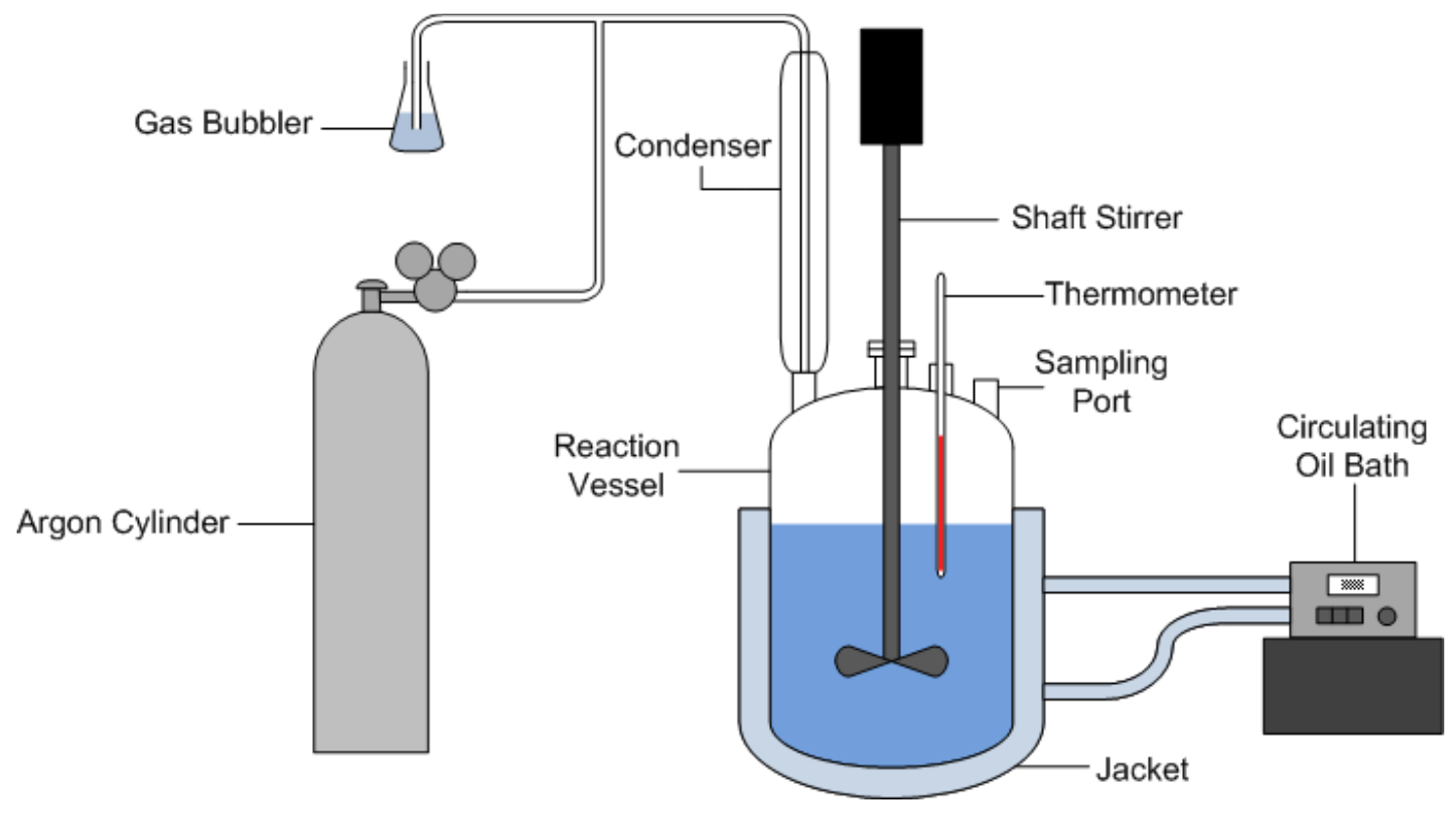


Fig. 11 


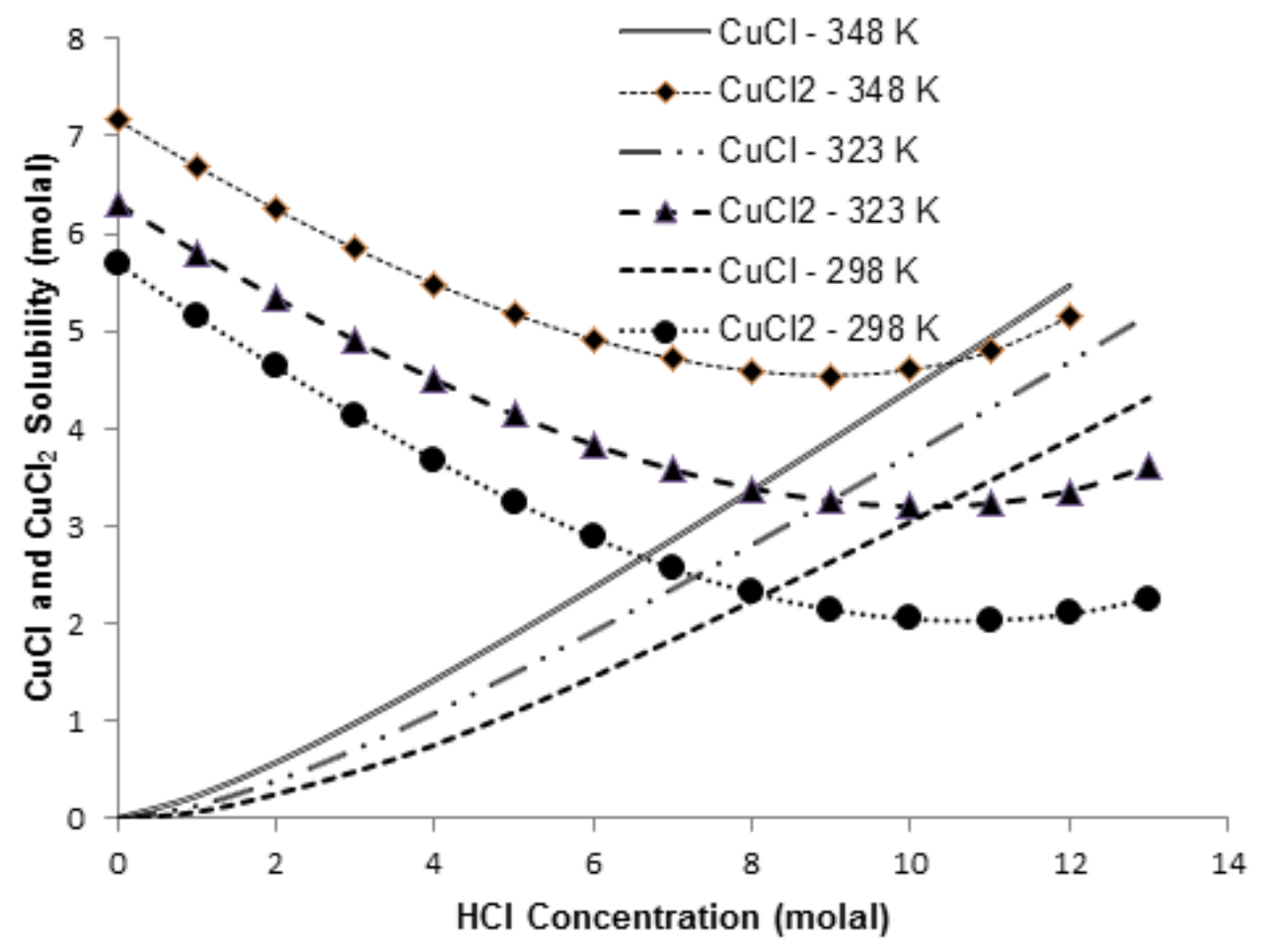

Fig. 12 


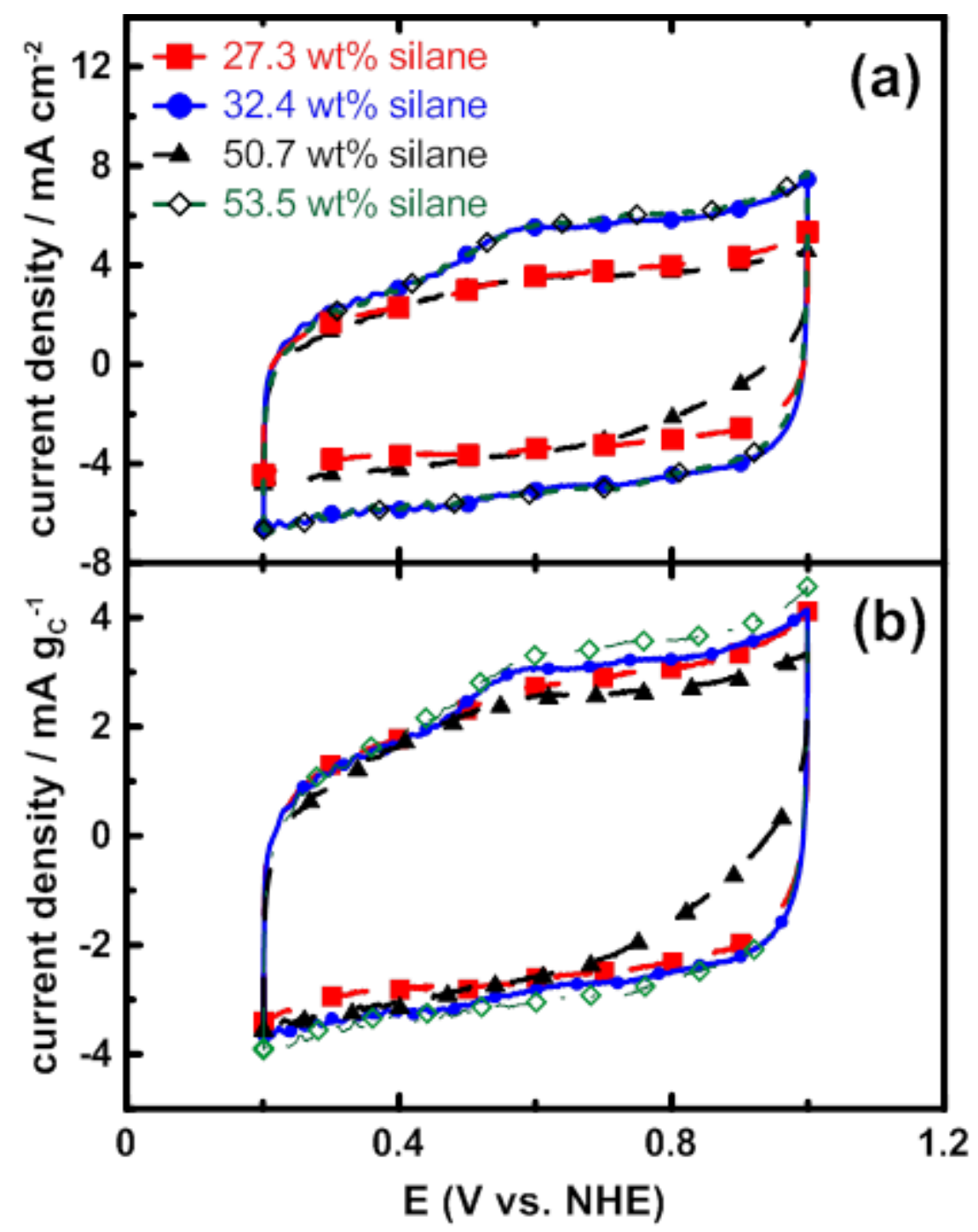

Fig. 13 


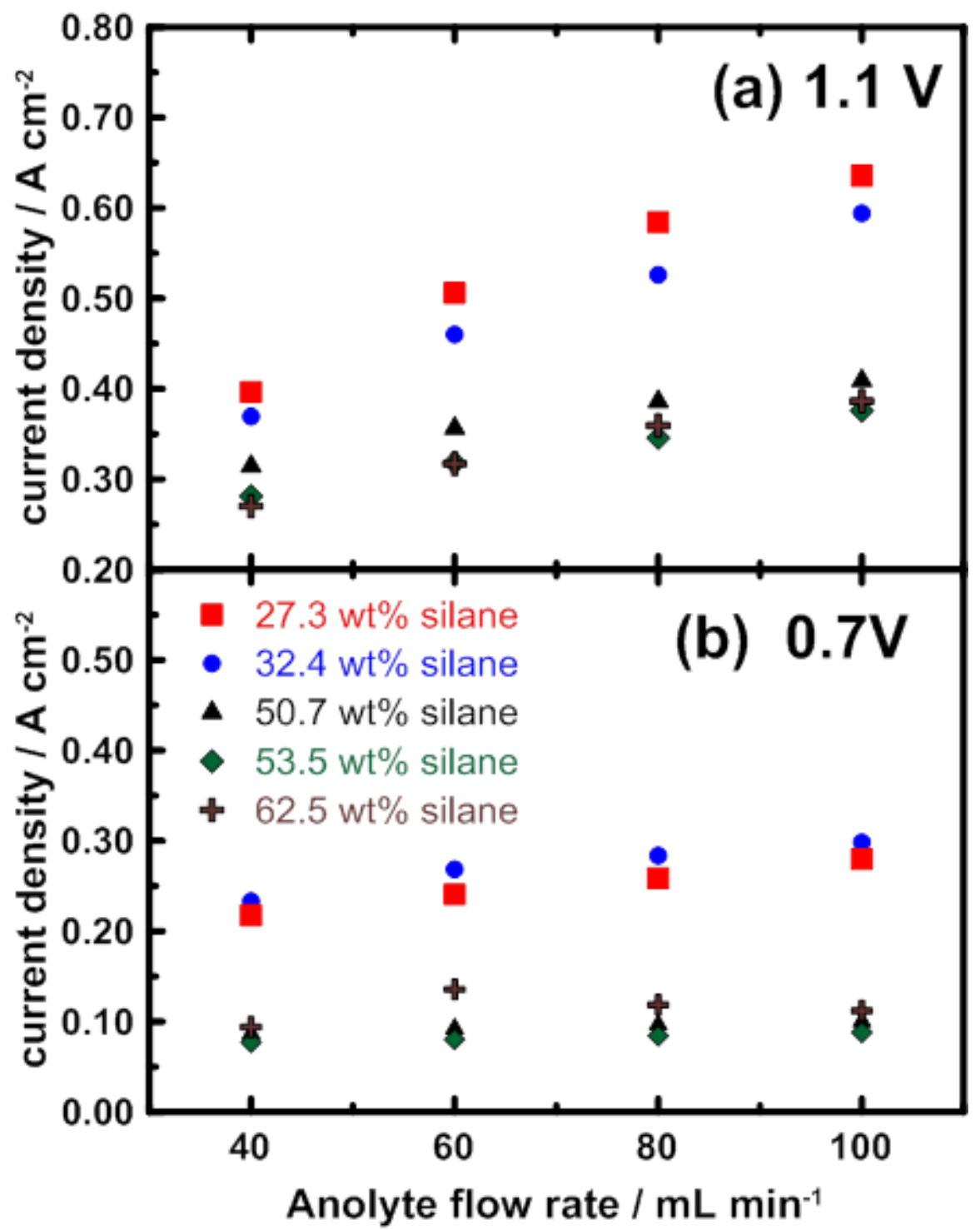

Fig. 14 


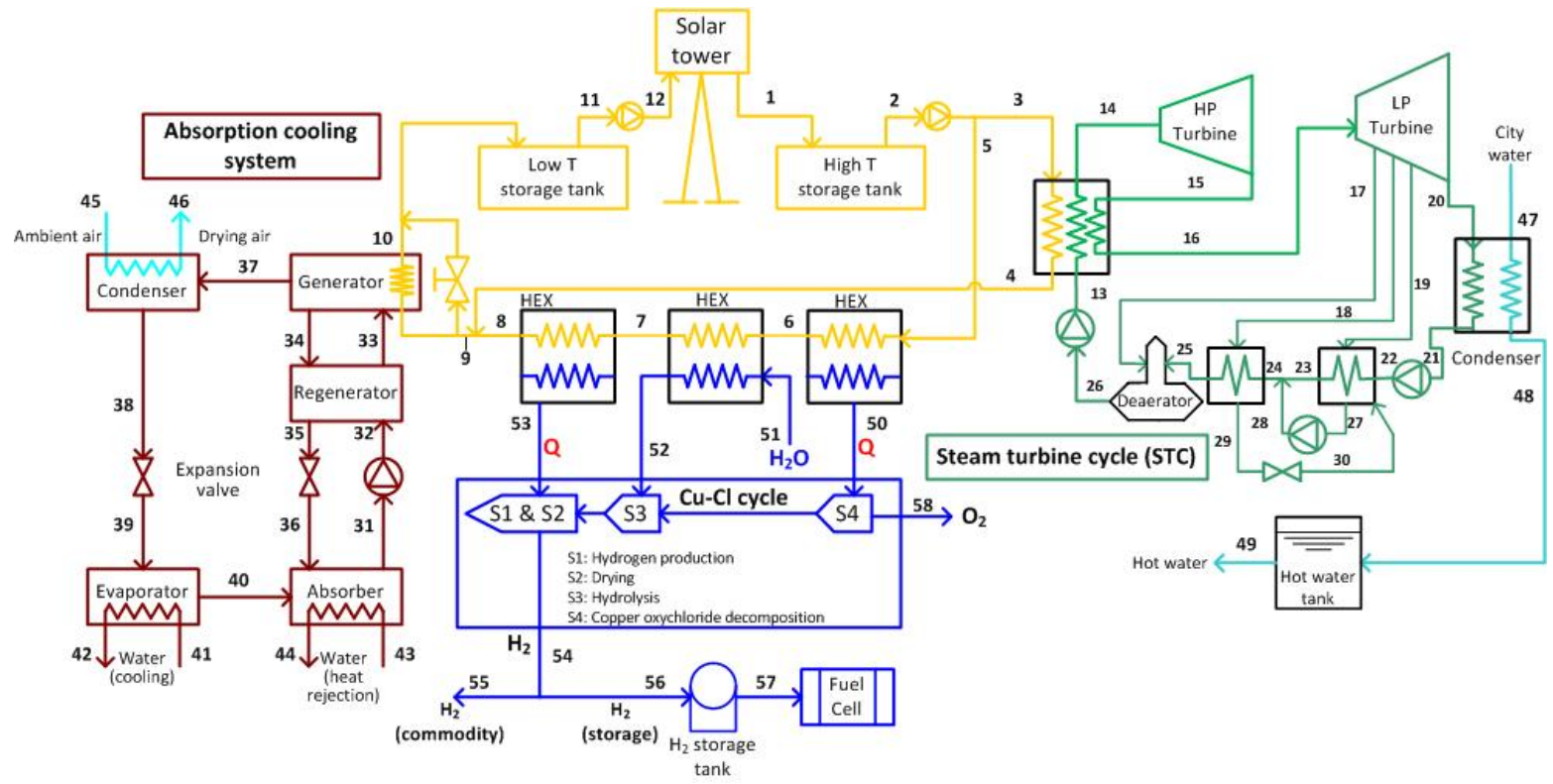

Fig. 15 


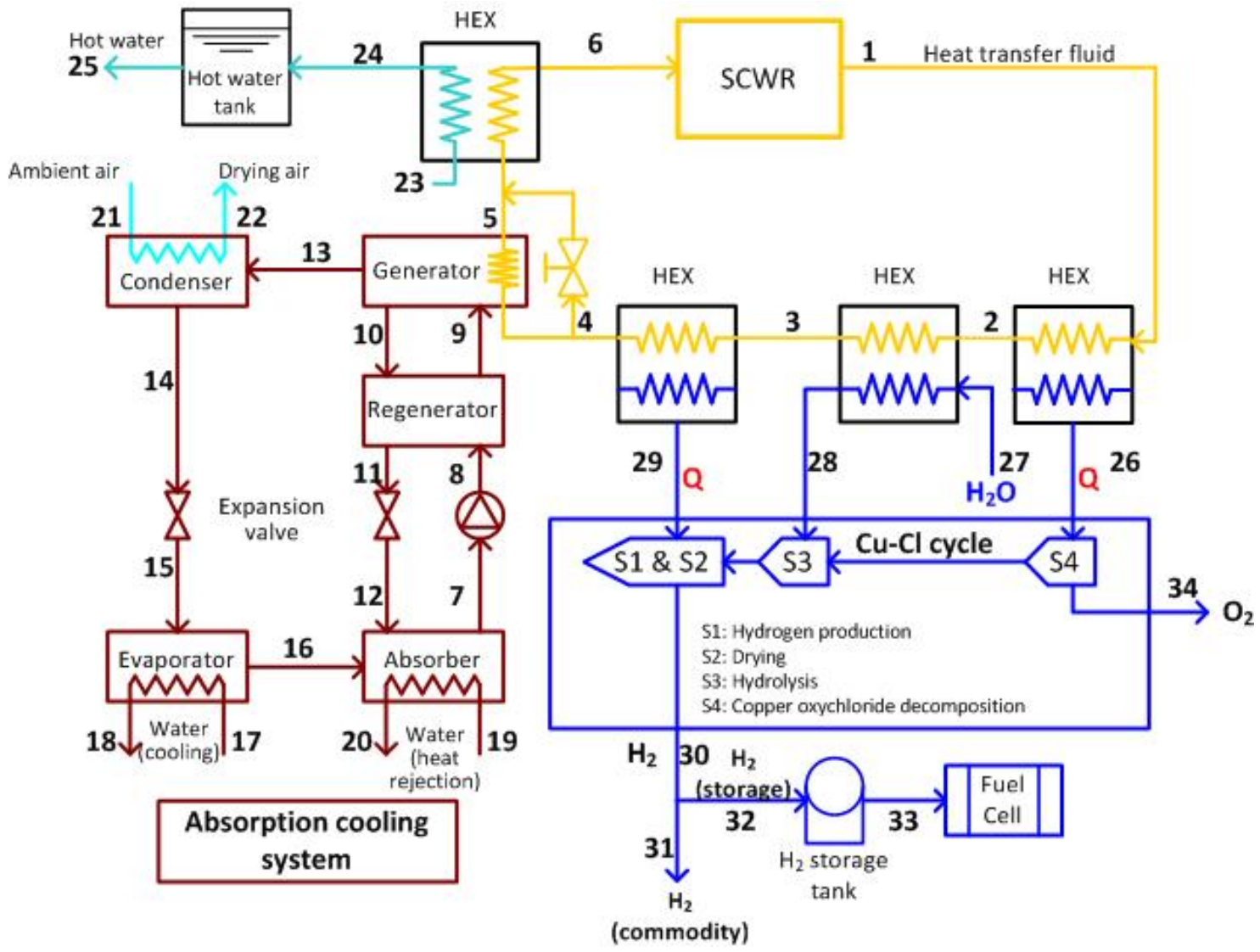


Fig. 16 


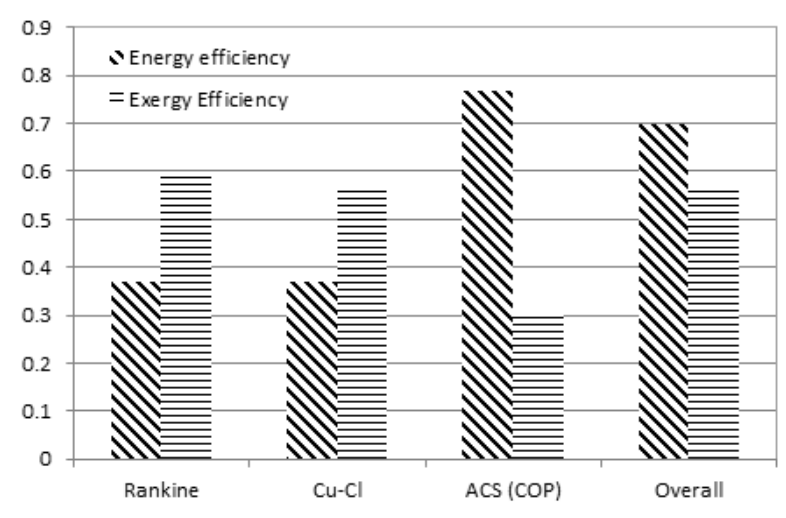

(a) Energy and exergy efficiency of System I and its sub-units

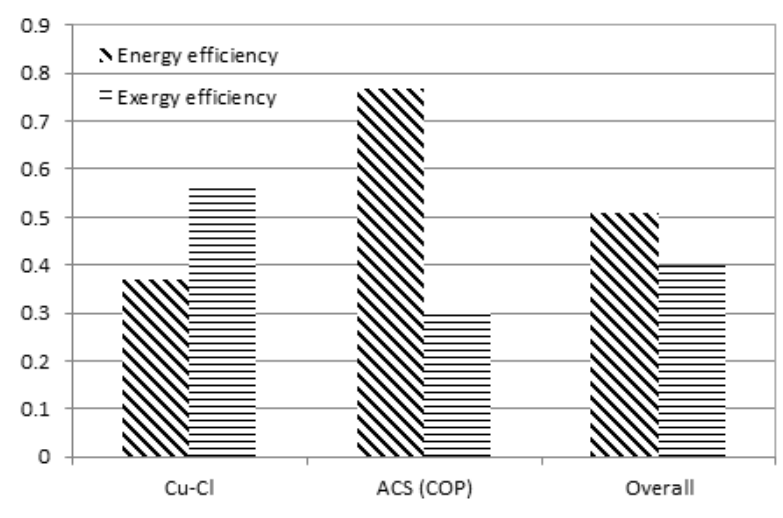

(b) Energy and exergy efficiency of System II and its sub-units.

Fig. 17 